\title{
Abnormalities of synaptic mitochondria in autism spectrum disorder and related neurodevelopmental disorders
}

\author{
Liliana Rojas-Charry ${ }^{1,2,3} \cdot$ Leonardo Nardi $^{1} \cdot$ Axel Methner ${ }^{2,3} \cdot$ Michael J. Schmeisser $^{1,3}$ (I)
}

Received: 3 September 2020 / Revised: 27 November 2020 / Accepted: 2 December 2020 / Published online: 18 December 2020

(C) The Author(s) 2020

\begin{abstract}
Autism spectrum disorder (ASD) is a neurodevelopmental condition primarily characterized by an impairment of social interaction combined with the occurrence of repetitive behaviors. ASD starts in childhood and prevails across the lifespan. The variability of its clinical presentation renders early diagnosis difficult. Mutations in synaptic genes and alterations of mitochondrial functions are considered important underlying pathogenic factors, but it is obvious that we are far from a comprehensive understanding of ASD pathophysiology. At the synapse, mitochondria perform diverse functions, which are clearly not limited to their classical role as energy providers. Here, we review the current knowledge about mitochondria at the synapse and summarize the mitochondrial disturbances found in mouse models of ASD and other ASD-related neurodevelopmental disorders, like DiGeorge syndrome, Rett syndrome, Tuberous sclerosis complex, and Down syndrome.
\end{abstract}

Keywords Autism spectrum disorder $\cdot$ ASD $\cdot$ Synapse $\cdot$ Mitochondria $\cdot$ Neurodevelopmental disorders

\section{Introduction}

Autism spectrum disorder (ASD) is a neurodevelopmental condition that starts in childhood and prevails across the lifespan, symptoms are variable, and a substantial increase in ASD diagnosis has been reported during the last 40 years [1]. A significant part of ASD cases is associated with mutations in synaptic proteins, suggesting an impairment of synaptic transmission as a primary underlying cause [2-7]. Synaptic activity is an energetically expensive process that consumes a large proportion of the adenosine triphosphate (ATP) generated in neurons, which is mainly produced by mitochondria through

Axel Methner

axel.methner@gmail.com

$\triangle$ Michael J. Schmeisser

mschmeisser@uni-mainz.de

1 Institute for Microscopic Anatomy and Neurobiology, University Medical Center of the Johannes Gutenberg-University, Duesbergweg 6, 55128 Mainz, Germany

2 Institute for Molecular Medicine, University Medical Center of the Johannes Gutenberg-University, Langenbeckstraße 1, 55131 Mainz, Germany

3 Focus Program Translational Neurosciences (FTN), University Medical Center of the Johannes Gutenberg-University, Mainz, Germany oxidative phosphorylation (OXPHOS) [8]. Mitochondria are present in approximately half of all presynaptic boutons, and synapses that contain mitochondria have more vesicles [9]. Postsynaptic mitochondria are less abundant and have a more tubular form than presynaptic mitochondria [10], indicating that distinct morphological changes in dendrites and axons occur to adjust their shape to energetic or other needs [11]. In addition, local synthesis of new proteins occurs in axons and dendrites and depends on mitochondria that provide energy during synaptic plasticity [12]. Besides their role as energy providers, mitochondria also act as calcium $\left(\mathrm{Ca}^{2+}\right)$ buffers that shape the synaptic response [13]. Hence, their presence at the synapse serves not only to produce ATP but also to control local $\mathrm{Ca}^{2+}$ concentrations $\left(\left[\mathrm{Ca}^{2+}\right]\right)$ and neurotransmitter release, which is essentially triggered by a sudden increase in $\mathrm{Ca}^{2+}$ concentration. The synaptic $\left[\mathrm{Ca}^{2+}\right]$ is tightly regulated by efflux through the plasma membrane and uptake into the spine apparatus, a sub-compartment of the smooth endoplasmic reticulum (sER), and mitochondria [14-17]. Genetically encoded $\mathrm{Ca}^{2+}$ sensors have provided evidence that individual hippocampal and cortical synapses with mitochondria accumulate less synaptic $\mathrm{Ca}^{2+}$ than those lacking these organelles [18, 19]. Based on the importance of synaptic signaling in ASD and the relevance of mitochondria in synaptic activity, we here aim to summarize the current knowledge about the role of synaptic mitochondria in ASD and other ASD-related neurodevelopmental disorders. 


\section{Functions of neuronal and synaptic mitochondria}

The brain consumes large amounts of oxygen-20\% of the whole body's consumption - and most of this oxygen is used to generate ATP through OXPHOS in mitochondria [8]. Mitochondria provide $93 \%$ of the ATP that the brain demands [20]. This ATP is used to support synaptic transmission, a very energy-demanding process. ATP is necessary to power ion pumps, support ion gradients, and maintain vesicle recycling and mitochondrial movement. Remarkably, the number of mitochondria in synaptic terminals and axons exceeds the predicted energy needs [20], which implies that they have additional functions at the synapse, like the buffering of intra-spine $\mathrm{Ca}^{2+}$ levels that directly influence the firing probability of neurons $[14,21]$.

The function of mitochondria as $\mathrm{Ca}^{2+}$ buffers and ATP producers also relies on the ER [22], which stores the highest concentrations of $\mathrm{Ca}^{2+}$ ions. The points of contact between the ER membrane and mitochondria are called mitochondria-ER contact sites (MERCs) or mitochondria-associated membranes (MAMs) [23]. MAMs are crucial for controlling $\mathrm{Ca}^{2+}$ concentrations in neurons through the ER channels inositol 1,4,5-trisphosphate receptors (IP3R), the sarcoendoplasmicreticulum $\mathrm{Ca}^{2+}$ ATPase (SERCA), the glucose-regulated protein 75 (Grp75), the voltage-dependent anion channel (VDAC1), and the mitochondrial $\mathrm{Ca}^{2+}$ uniporter (MCU) [24]. Another $\mathrm{Ca}^{2+}$ modulator, the receptor chaperone Sigma 1 (S1R), localizes in MAMs in a complex with type 3 IP3R [25]. Other tethering complexes are formed by proteins like the protein tyrosine phosphatase-interacting protein 51 (PTPIP51), the vesicle-associated membrane proteinassociated protein B (VAPB), and the B cell receptorassociated protein (BAP31), which are also associated with $\mathrm{Ca}^{2+}$ handling [26]. Interestingly, mutations in VAPB and $\mathrm{S} 1 \mathrm{R}$ are related to neurodegenerative diseases $[27,28]$. MAMs are frequent in neurons, and besides the regulation of $\mathrm{Ca}^{2+}$ signaling, they are involved in synaptic transmission, since the absence of VAPB-PTPIP51 in synapses leads to a reduced number of dendritic spines and decreased synaptic activity $[29,30]$.

Cytosolic $\mathrm{Ca}^{2+}$ ions that enter the mitochondrial matrix through the MCU increase OXPHOS by stimulating pyruvate dehydrogenase phosphatase rendering the pyruvate dehydrogenase complex more active [31]. $\mathrm{Ca}^{2+}$ also activates other citrate cycle enzymes, like isocitrate dehydrogenase and alpha-ketoglutarate dehydrogenase [32, 33]. Besides MCU, additional mitochondrial uptake mechanisms have been identified in heart and liver cells, like the mitochondrial ryanodine receptor (mRyR) and the rapid mode of uptake (RaM) [34-36]. $\mathrm{Ca}^{2+}$ release into the cytosol is executed through either the mitochondrial permeability transition pore (mPTP) or the $\mathrm{Na}^{+} / \mathrm{Ca}^{2+}$ exchanger (mNCX) $[37,38]$. The increase in cytosolic $\mathrm{Ca}^{2+}$ triggers synaptic vesicle exocytosis and, consequently, neurotransmitter release. Mitochondrial $\mathrm{Ca}^{2+}$ uptake inhibition contributes to increased cytosolic $\mathrm{Ca}^{2+}$, which causes depletion of synaptic vesicles [39]. See Fig. 1 for a representation of the MAM proteins and their role in ERmitochondrial $\mathrm{Ca}^{2+}$ transfer.

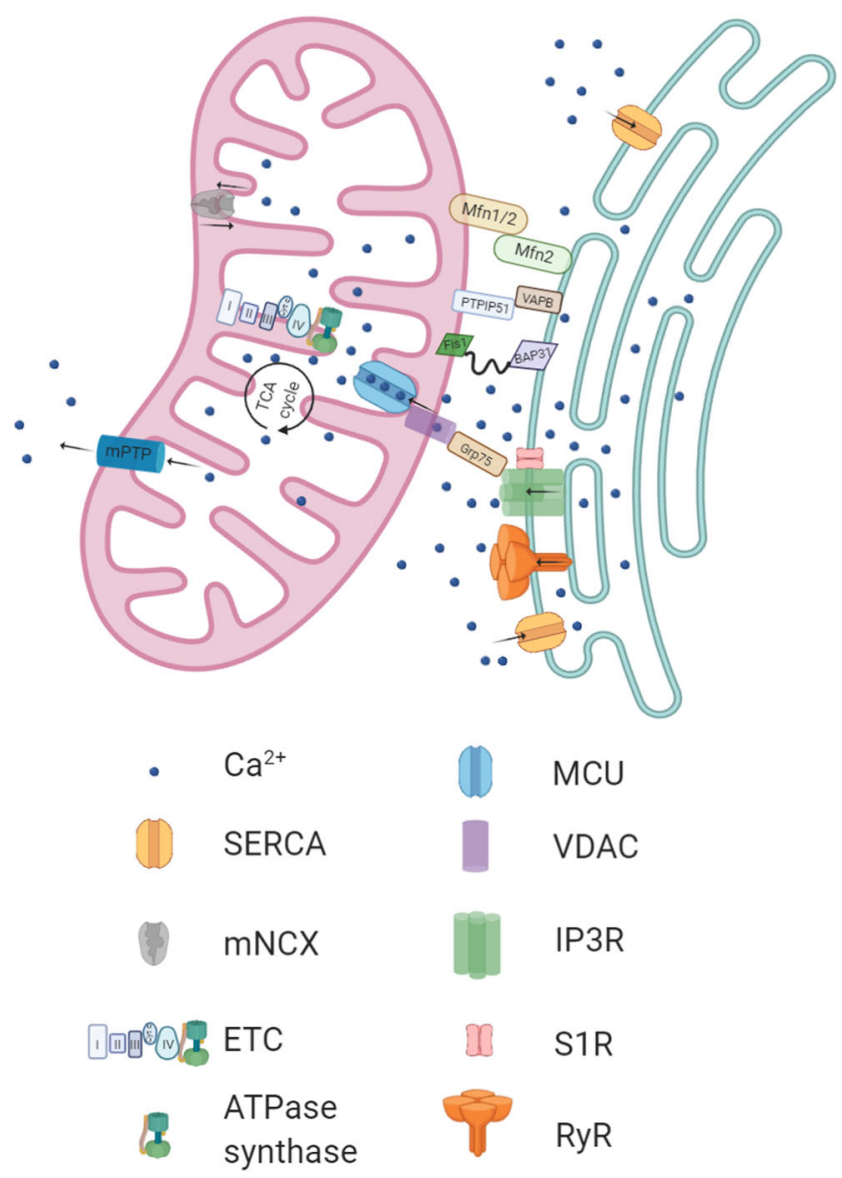

Fig. 1 Mitochondrial-ER contact sites in neurons. The endoplasmic reticulum (ER) and mitochondria are connected by several proteins depicted here. Mitofusin 2 (Mfn2) regulates the tethering between the two organelles by a direct interaction through its heptad repeat domains (HR)[40]. Mitofusin 1 (Mfn1) participates in this process and remains in the mitochondria. Other proteins like tyrosine phosphatase-interacting protein 51 (PTPIP51) and the vesicle-associated membrane proteinassociated protein B (VAPB) also build bridges to connect both organelles [26]. The mitochondrial fission protein (Fis1) forms a complex with the B cell receptor-associated protein (BAP31) that signals for apoptosis [41]. The sarcoendoplasmic-reticulum $\mathrm{Ca}^{2+}$ ATPase (SERCA) transports $\mathrm{Ca}^{2+}$ into the ER. The $\mathrm{Ca}^{2+}$ release channel, inositol 1,4,5-trisphosphate receptor (IP3R), is composed of 4 subunits [42] and interacts with a $\mathrm{Ca}^{2+}$ modulator, the receptor chaperone Sigma 1 (S1R). The ryanodine receptor (RyR) is another $\mathrm{Ca}^{2+}$ release channel. $\mathrm{Ca}^{2+}$ ions enter the mitochondrial matrix through the mitochondrial calcium uniporter (MCU) and activate enzymes that stimulate the tricarboxylic acid (TCA) cycle and the electron transport chain (ETC) [31-33]. Excessive $\mathrm{Ca}^{2+}$ ions are released into the cytosol through the mitochondrial permeability transition pore (mPTP) and the $\mathrm{Na}^{+} / \mathrm{Ca}^{2+}$ exchanger (mNCX) [37, 38]. Arrows indicate the direction of $\mathrm{Ca}^{2+}$ flow. Created with BioRender.com 
Mitochondria are not entirely uniform in individual cells; they vary in size, morphology, and metabolic activity [43]. In axons, mitochondria are mostly round and not so numerous compared with perinuclear mitochondria, which form complicated networks. In general, mitochondria are dynamic organelles that adapt their morphology and distribution in neurons to fulfill specific needs $[44,45]$. The constant shape change of mitochondria is called mitochondrial dynamics. It involves fusion and fission processes performed by a set of specific mitochondrial proteins involved in several diseases [46-48]. Mitochondria fuse to form networks, repair their damage, and share genetic information [49]. Mitochondrial fusion is accomplished by the GTPases Mitofusin $1(\mathrm{Mfn} 1)$ and Mitofusin 2 (Mfn2), localized in the outer mitochondrial membrane (OMM). The process occurs through their hydrophobic domains, essential for association with other Mfns in proximal mitochondria $[40,50]$. Another protein involved in this process is the dynamin-like $120 \mathrm{kDa}$ protein or optic atrophy protein 1 (Opa1), which is anchored in the inner mitochondrial membrane (IMM) and necessary for the formation of cristae [51]. The conditional knockout of Mfn2 causes neurodegeneration in the hippocampus and cortex and increased oxidative stress [52]. Mfns also form bridges between the ER and mitochondria [53], and the mutation of MFN2 is associated with hereditary Charcot-Marie-Tooth disease [54, 55].

Another dynein-like GTPase, the dynein-related protein 1 (Drp1), controls mitochondrial fission in neurons. Drp1 is found in the cytosol, oligomerizes, and is transported to mitochondria to constrain membranes by protein adaptors like the mitochondrial fission protein (Fis1), the mitochondrial fission factor (Mff), the mitochondrial dynamics protein 51 (MiD51/ MIEF1), and the mitochondrial dynamics protein 49 (MiD49/ MIEF2) [56]. Drp1 is the subject of several post-translational modifications that impact its activity. In neurons, phosphorylation of Drp1 at Ser616 by cyclin-dependent kinase 1 (CDK1) stimulates mitochondrial fragmentation. Meanwhile, phosphorylation at Ser637 by protein kinase A (PKA) and $\mathrm{Ca}^{2+} /$ calmodulin-dependent protein kinase $\mathrm{I} \alpha$ $(\mathrm{CaMKI} \alpha)$ inhibits mitochondrial fission [57, 58]. Modifications like nitrosylation promote Drp1 phosphorylation at Ser616, and consequently, mitochondrial fission in primary hippocampal neurons [59, 60]. Mitochondrial fusion and fission need to be balanced for neuronal health [61]. The deletion of Drp1 in adult mouse forebrain impairs spatial working memory and synaptic function [62, 63]. Reduced oxygen consumption and ATP concentrations are also found in isolated mitochondria from the hippocampal region.

The postsynaptic compartment is critical for triggering long-term potentiation (LTP), which underlies learning and memory formation. A recent study provides evidence about the interplay between mitochondrial fission and LTP [64]. The expression of a dominant-negative mutant of Drp1 that prevents mitochondrial fission in primary hippocampal neurons impairs LTP in cultured cells and hippocampal slices. Nevertheless, this study was performed in vitro. The relationship between LTP and mitochondrial dynamics is still unknown for in vivo models. It is also unclear whether mitochondrial morphology regulation solely depends on the increase of cytosolic $\left[\mathrm{Ca}^{2+}\right]$, which takes place as the triggering step for synaptic signaling. The $\mathrm{Wnt} / \mathrm{Ca}^{2+}$ signaling pathway is considered a regulator of mitochondrial dynamics at the postsynapse. The stimulation of hippocampal CA1 slices with the ligand Wnt-5a influences the morphology and the number of mitochondria in this compartment as measured by transmission electron microscopy, probably through the phosphorylation of Drp1, which was found augmented at Ser-616 and decreased at Ser-637, leading to mitochondrial fission [65]. A study from 2018 showed that neurons devoid of Mff release less presynaptic vesicles, providing further evidence of the essential role of mitochondrial morphology in synaptic activity [66].

Fragmented mitochondria are also related to mitophagy, a particular mechanism to remove unhealthy mitochondria observed in the soma and distal axons [67-69]. Damaged mitochondria are eliminated in a process regulated by the PTENinduced putative kinase 1 (PINK1) and Parkin, a cytosolic E3 ubiquitin ligase. Under mitochondrial stress conditions, PINK1 remains in the OMM and phosphorylates ubiquitin on Ser65, which translocates Parkin to the mitochondria and initiates the degradation of the defect organelles through autophagy [70,71]. The removal of dysfunctional mitochondria is required for preserving neuronal homeostasis [72, 73]. The PINK-Parkin pathway is the most-studied mechanism because mutations in these proteins are linked to the familial forms of Parkinson's disease [74]. However, in vivo studies demonstrated that mitophagy also occurs in the absence of Pink1 in different populations of dopaminergic neurons, concluding that other mitophagy pathways exist [75]. This study also presented evidence that the expression of Pink1 differs according to brain region, being most extensively expressed in the striatum, neocortex, cerebellum, and spinal cord.

Mitochondria are also actively transported within axons to reach distant parts according to the energy requirements, mediated by AMPK signaling [76]. There is a direct correlation between synaptic activity and the transport and distribution of mitochondria [77]. During synaptic activity, mitochondria remain at presynaptic terminals and postsynaptic dendritic spines [78]. The transport of mitochondria is performed by a specialized machinery that works together with the cytoskeleton. It has been studied mainly in neurons due to the long distances these organelles travel to reach their destinations. The anterograde transport is mediated by Kinesin-1, which attaches to mitochondria through anchoring proteins like the $\mathrm{Ca}^{2+}$-sensing protein mitochondrial Rho GTPase 1 (Miro1), the microtubule-based motors dynein-dynactin, and the motor adaptors trafficking kinesin protein 1 and 2 (TRAK1 and 
TRAK2) [79, 80]. The retrograde movement is less well characterized but driven by the motor adaptor TRAK2 associated with dynein, which constitutes the essential retrograde mitochondrial motor [81]. Mitochondrial axonal transport during synaptic activity is also regulated by syntaphilin (SNPH), a protein that binds to Kinesin-5 to immobilize mitochondria. Presumably, SNPH anchors mitochondria to the microtubules [82]. One study performed in primary cortical neurons demonstrated that SNPH facilitates the removal of damaged mitochondria in axons by forming vesicles with late-endosomes, independently of the mitophagy system [83]. Interestingly, a recent study performed in ganglion cell dendrites of the intact retina challenged the accepted view of mitochondria as highly mobile organelles [84]. Faits et al. found that dendritic mitochondria remain stationary in mature neurons even when stimulated with $\mathrm{Ca}^{2+}$ transients, showing the complexity of mitochondrial positioning in dendrites and the differences found in cultured cells and whole tissues.

Most studies on mitochondrial function at synapses have focused on the presynaptic specialization, while the role of postsynaptic mitochondria is less explored. The postsynaptic density (PSD) is a highly specialized compartment that contains hundreds of different proteins that constantly change composition according to synaptic activity. Mitochondria are mainly seen in the dendritic shafts, but they can also reach spines [85]. Studies performed in hippocampal neurons demonstrate that reducing the mitochondrial content in dendrites decreases the number of spines and synapses [78].

Although the current understanding of the role of mitochondria at the synapse has considerably increased (see Fig. 2 for a summary), many essential questions remain unanswered. One is how synapses without mitochondria handle energy requirements. Another one is whether and how distinct neuronal populations differ in mitochondrial shape and function since most studies have been performed in hippocampal and cortical neurons.

\section{Mitochondrial dysfunction in ASD}

\section{ASD caused by mutations and loss of function of SH3 and multiple ankyrin repeat domains (SHANK) proteins}

Several neurodevelopmental disorders are characterized by a combination of metabolic disease and synaptic disturbances $[92,93]$. SHANK proteins, for example, predominantly serve as adaptor and scaffolding proteins in the PSD and connect ionotropic and metabotropic glutamate receptors (mGluR) with the actin cytoskeleton [94]; their mutations are implicated in multiple neuropsychiatric disorders, including ASD, schizophrenia, and intellectual disability to name the most frequently occurring [95-99].
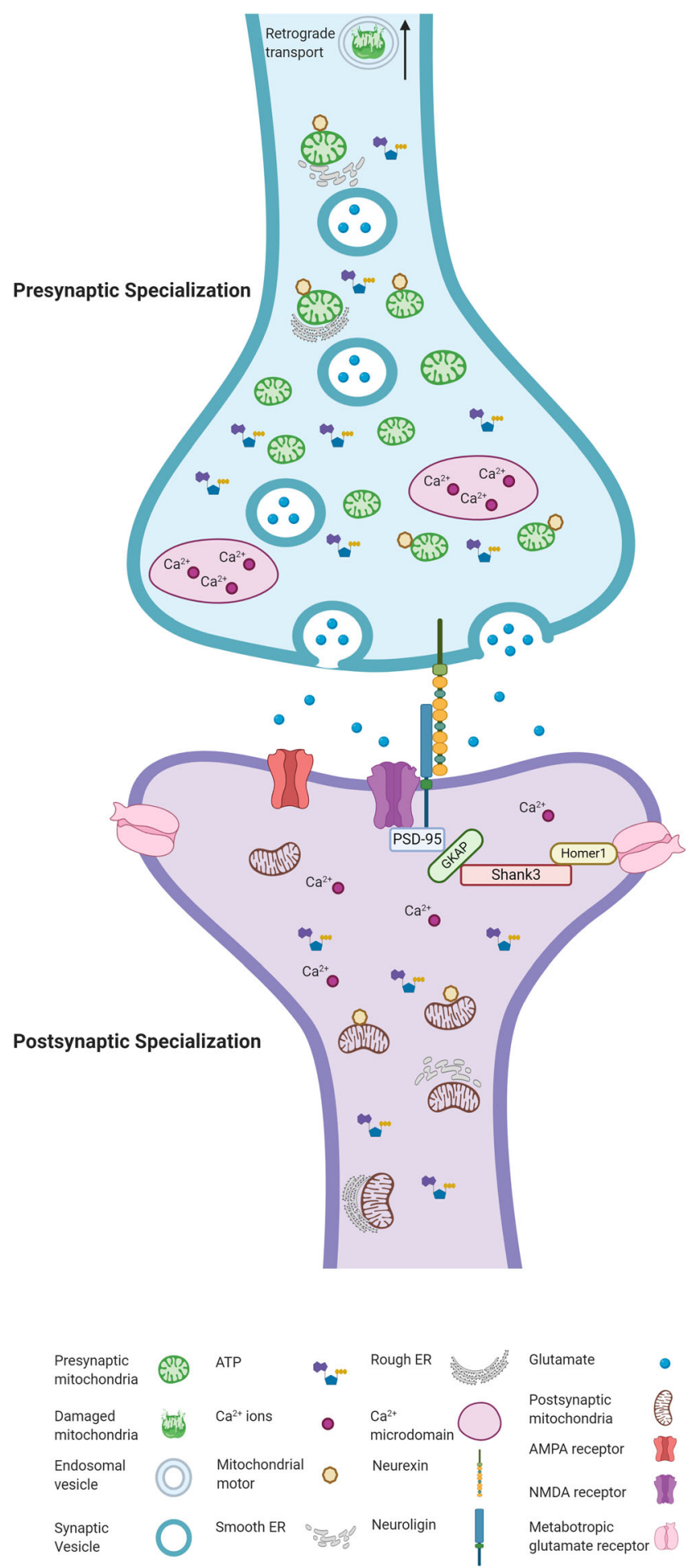

Proteomic analysis of Shank3 complexes isolated by immunoprecipitation from synaptosomal fractions found an interaction of Shank3 with several mitochondrial proteins [100]. In this study, synaptosomal fractions were treated with different concentrations of $\mathrm{ZnCl}_{2}$, which binds to the $\mathrm{C}$-terminal alpha motif domain of Shank3 and promotes its scaffolding and stabilization at the PSD. Interestingly, several mitochondrial proteins were identified in the interactomes analyzed 
Fig. 2 Synapse structure and mitochondria. The figure represents some of the recognized mitochondrial functions in a glutamatergic synapse. Presynaptic mitochondria are smaller and more abundant than postsynaptic mitochondria in the hippocampus [86]. Postsynaptic mitochondria have dense cristae, and tubular shapes, and make contacts with the ER [10,87]. Mitochondrial movement increases in axons and is greater than in dendrites, although some mitochondria remain stationary (represented by the absence of mitochondrial motors) [88]. Not all of the presynaptic boutons contain mitochondria (only less than half), but the synapses with mitochondria have more vesicles and are associated with increased synaptic activity $[9,89]$. Augmented $\mathrm{Ca}^{2+}$ concentrations are detected in microdomains (depicted in ovals) [90]. Neurexin, Neuroligin, and SHANK are synaptic scaffolding proteins implicated in ASD [91]. Abbreviations: PSD-95 (postsynaptic density protein 95); GKAP (guanylate kinase-associated protein). Created with BioRender.com

after $\mathrm{Zn}^{2+}$ induction, including core subunits of the mitochondrial membrane ATP synthase, the NADH dehydrogenase 1, the cytochrome c oxidase, and the ADP/ATP translocase 4, accounting for $22 \%$ of the proteins identified. This work was performed in Shank3-overexpressing mice.

Phelan McDermid syndrome (PMS), or 22q13.3 deletion syndrome, is characterized by different symptoms, including developmental delay, speech difficulties, and ASD-like behavior. This syndrome is caused by the loss of one functional copy of SHANK3 [101]. Mitochondrial dysfunction can theoretically contribute to the clinical variability in PMS since six mitochondrial genes are adjacent to SHANK3 in the 22q13.3 region [102]. These genes include cytochrome c oxidase assembly (SCO2) involved in the assembly of the cytochrome c oxidase; NADH dehydrogenase 1 alpha subcomplex subunit 6 (NDUFA6), which is necessary for the assembly of complex I of the respiratory chain; thymidine phosphorylase (TYMP), and tRNA 5-methylaminomethyl-2-thiouridylate methyltransferase (TRMU), both involved in mitochondrial DNA; carnitine palmitoyltransferase $1 \mathrm{~B}(C P T 1 B)$, essential for fatty acid metabolism and aconitase 2 (ACO2), that participates in tricarboxylic acid cycle (TCA) function. In the study published by Frye et al., the activities of mitochondrial complexes I and IV were impaired when measured in the saliva of 51 individuals diagnosed with PMS [102]. Although the connection between mitochondrial dysfunction and the decline in complexes I and IV activity matches the function of the mitochondrial genes found in chromosome 22q13, little is known about the biological mechanisms between SHANKs and mitochondrial function at the excitatory synapse.

\section{ASD associated with mutations and loss of function of fragile $\mathrm{X}$ mental retardation protein}

Other ASD-related proteins are not primarily associated with synaptic scaffolding but play a crucial role in synaptic signaling processes. One example is fragile $\mathrm{X}$ mental retardation protein (FMRP) encoded by the FMR1 gene, which, when deleted, increases mGluR signaling [103, 104]. Expansions of a CGG repeat in the FMRI gene exceeding 200 bp produce a full mutation that causes the fragile X syndrome (FXS), characterized by autistic-behaviors and intellectual disability [105]. Individuals that carry the trinucleotide CGG repeat expanded between 55 and 200 bp are called premutation carriers; they do not develop FXS, but due to gene instability, the premutation expands to the full mutation, affecting the offspring [106]. Regarding metabolic function, one pioneer study showed that the brains of Fmrl-knockout (KO) mice had increased levels of reactive oxygen species (ROS), alterations in the expression of glutathione (GSH) in whole brains, and increased production of NADPH oxidase in specific brain regions like the cerebellum, hippocampus, and prefrontal cortex (PFC) when compared to wild-type (WT) mice [107]. Primary hippocampal neurons obtained from Fmrl-knockin (KI) premutation mice showed a decreased population of mitochondria and reduced mitochondrial trafficking [108]. Another study performed in primary neurons from Fmrl$\mathrm{KO}$ mice found reduced expression of Opa1, Mfn1, and Mfn2, together with more mitochondrial fragmentation [109]. The mitochondrial fusion phenotype was rescued by increasing the expression of endogenous Huntingtin (Htt), the protein implicated in Huntington's disease. Interestingly, $\mathrm{Htt}-\mathrm{KO}$ mice display behavioral features similar to Fmrl-KO mice, and treatment with M1, a phenylhydrazone that permeates the cell membrane, enhances mitochondrial fusion, and restores the behavioral deficiencies in mice lacking either Fmr1 or Htt.

Mitochondrial-enriched fractions were obtained from the cortex, the hippocampus, and the cerebellum of a premutation Fmr1-KI mouse model. Respiration deficits were found in the hippocampus of very young animals (21 days old), characterized by lower ATP production and lower expression levels of the ATPase $\beta$-subunit (ATPB) [110]. This study emphasizes that the mitochondrial pools analyzed were non-synaptic. Here, the authors found altered gene expression of the $\mathrm{Zn}^{2+}$ transporters ZnT4 and ZnT6 in the mammary glands of Fmr 1$\mathrm{KI}$ dams producing reduced concentrations of $\mathrm{Zn}^{2+}$ in breast milk. They propose that adequate concentrations of dietary $\mathrm{Zn}^{2+}$ are necessary to restore normal brain metabolism [111]. Disturbances in $\mathrm{Zn}^{2+}$ metabolism were found in the fibroblasts from premutation individuals, possibly because of the expanded repeats that, upon accumulation, modify miRNAs processing [112].

Impaired mitochondrial energy metabolism was also reported in a study performed in the cortex of juvenile (21 days old) and adult (1-year-old) Fmr 1-KO mice. Increased activities of the OXPHOS complexes were detected spectrophotometrically in mitochondrial membranes isolated from the cortex, but a lower ATP production was found. Similar observations were made in the striatum and cerebellum. No enhancement in the activities of the enzymes of the glycolytic pathway 
was present [113]. Isolated mitochondria from the forebrain of Fmr1-KO mice exhibited decreased mitochondrial respiration driven by complexes I and II. Reduced expression levels of ubiquinone quantified by HPLC and spectrophotometry were also detected. This study identified an augmented proton leak accompanied by reduced mitochondrial $\mathrm{Ca}^{2+}$ uptake that could be reversed by treatment with ubiquinone analogs in vivo and in vitro [114]. It is, therefore, not clear how Fmr1 deficiency promotes the uncoupling of respiration in this model.

A recently published study identified the translation of mitochondrial proteins in isolated synaptosomes from whole brains [115]. Kuzniewska et al. found newly synthesized mitochondrial proteins using in vitro stimulation of mouse synapses and mass spectrometry. They also analyzed the morphology and function of the synaptic mitochondria from Fmr1-KO mice and found more dysmorphic mitochondria and increased oxygen consumption than WT mice when measured by high-resolution respirometry.

To summarize, there is accumulating evidence showing mitochondrial dysfunction in different Fmrl mutant models, including Drosophila [116]. Although some of the findings point to an indirect relationship, others suggest that altered translation of mitochondrial proteins at the synapse is a possible mechanism behind disorders like FXS. More studies are necessary to understand how mitochondria contribute to the development of the FXS or if impairments in mitochondrial function are just an epiphenomenon.

\section{ASD-related neurodevelopmental disorders}

\section{DiGeorge syndrome}

The DiGeorge syndrome, also known as velocardiofacial or $22 \mathrm{q} 11.2$ deletion syndrome (22q11.2DS), is the consequence of a hemizygous microdeletion (1.5-3 Mb) on chromosome 22 , with an incidence of 1 in 4000 [117]. The syndrome often presents with different neuropsychiatric symptoms [118], including schizophrenia [119]. Additionally, individuals with 22q11.2DS manifest with attention-deficit hyperactive disorder (ADHD), ASD, anxiety, depressive, and bipolar disorders $[120,121]$.

Recent research in a hemizygous mouse model with a 1.5$\mathrm{Mb}$ deletion in chromosome 22q11 (LgDel 22q11) demonstrates that stabilization and enhancement of mitochondrial function by the administration of $\mathrm{N}$-acetyl cysteine constitute a viable therapeutic approach to treat cortical underconnectivity [122], a frequent pathogenic feature in neurodevelopmental disorders. Mitochondria are affected in this study, specifically in cortical layer $2 / 3$, with morphological impairments characterized by the absence of cristae and increased ROS production in the mitochondria and the cytosol.
This study highlights the relevance of mitochondria in synapses and their implications in normal and neuronal disease states and emphasizes existing differences in the mitochondrial population depending on brain regions. Others reported alterations in the mitochondrial proteome of the hippocampus and prefrontal cortex in a 22q11.2 microdeletion mouse model [123]. Specifically, the mitochondrial transporters encoded by Slc25a1-Slc25a4 appear to play a significant role in synapse formation. Likewise, reduced expression of another gene located on 22q11.2, the gene encoding the mitochondrial large ribosomal subunit protein 40 (Mrpl40), impairs short-term potentiation (STP) and mitochondrial $\mathrm{Ca}^{2+}$ buffering properties in axons of the CA3 hippocampal region [124]. Although no mitochondrial morphology changes were detected, overexpression of the mitochondrial adenine nucleotide translocase protein (Ant1) encoded by the Slc25a4 gene recovered the STP to WT levels, supporting the role of mitochondrial transporters in this microdeletion syndrome.

\section{Rett syndrome}

Rett syndrome (RS) is the result of mutations in the X-linked gene methyl-CpG-binding protein 2 (MECP2). Patients with RS have impairments in language and communication, learning and coordination and they show autistic-like behaviors $[125,126]$. The syndrome also presents with motor difficulties and microcephaly and patients grow slower than other children [127]. More elongated mitochondria were identified in the dendrites and axons from the hippocampus of a mouse model lacking exons three and four of the Mecp 2 gene (Mecp2B) compared to WT [128]. The hippocampus from male Mecp 2 mutant mice also displays an increased expression of superoxide dismutase 1 (SOD1) and downregulation of the $\mathrm{Ca}^{2+}$ channel Cacnalg, resulting in augmented oxidative stress as detected by optical recordings obtained with the redox probe roGFP1 - that measures both mitochondrial and cytosolic ROS content-in hippocampal slices [129]. Oxidative damage was also detected in whole brains of Mecp2-KO and Mecp2-308 mutant mice [130]. The treatment with free radical scavengers like Trolox-a derivative from vitamin E-rescued mitochondrial functionality and restored synaptic LTP in the hippocampus and hippocampal astrocytes of this RS mouse model $[131,132]$. Other compounds such as metformin and quercetin rescued the mitochondrial phenotype in whole brains of Mecp2-308 mutant mice and primary astrocytic cultures, respectively $[133,134]$. The downregulation of Mecp2 in microglia generates increased oxygen consumption, less ATP production, and overexpression of Snat $1-\mathrm{a}$ glutamine transporter encoded by Slc38a1, a Mecp2 target gene previously identified in a ChIP-seq assay [135]. Mecp2 intervenes in regulating the expression of Slc25a4 encoding Ant1 [136]. Forlani et al. found increased mRNA expression of Slc25a4 in whole brains and the cerebellum of Mecp2-KO 
mice. Ant1 has been associated with mitochondrial disorders like Senger's syndrome, in which skeletal muscle mitochondria are impaired [137, 138]. Another mitochondrial gene found overexpressed in the cortex and cerebellum of Mecp2KO mice is Prodh, which encodes the proline oxidase protein localized in the inner-mitochondrial membrane [139]. Mutations in proline oxidase are associated with behavioral deficits, epilepsy, and intellectual disabilities [140].

Furthermore, it was shown that the brains of Mecp2-308 mutant females produce more hydrogen peroxide $\left(\mathrm{H}_{2} \mathrm{O}_{2}\right)$ and exhibit a decreased mitochondrial membrane potential $\left(\Psi_{\mathrm{m})}\right.$ and diminished mitochondrial ATP production [141]. This study also found reduced activities of the respiratory chain complexes in the hippocampus and cortex, measured by spectrophotometric assays. Complexes I, II, and V were specifically less active in the cerebellum and striatum. The treatment of these mice with cytotoxic necrotizing factor 1 (CNF1), a bacterial protein previously used for ameliorating the behavioral phenotype in the same mouse model, recovers the activities of the respiratory complexes to WT levels [142]. It was also reported that mitochondrial dysfunction could be recovered after treatment with the selective agonist LP-211, which stimulates the brain serotonin receptor 7 (5-HT7R). However, no underlying mechanisms about the role of serotonin and mitochondria in this syndrome have been established [143].

A study performed in isolated mitochondria from the hippocampus and cortex of Mecp2-KO mice indicated that hippocampal and cortical mitochondria are impaired as they release more ROS and consumed more $\mathrm{O}_{2}$ compared to WT littermates [144]. Still, it is unclear if the mitochondrial defects found in these disease models can be solely attributed to increased respiration and if these alterations are the consequence of redox imbalances. Similar results were obtained in a previous study performed in isolated mitochondria from whole brains of Mecp2-KO mice that also found significantly higher respiration rates than WT, and the mitochondrial ubiquinolcytochrome c reductase core protein 1 (Uqcrcl) gene was upregulated [145]. To summarize, there is considerable evidence linking RS and mitochondrial dysfunction in patients and animal models of the disease [146]. Interventions targeting mitochondria might be beneficial in the treatment of RS.

\section{Tuberous sclerosis complex}

Tuberous sclerosis complex (TSC) is a rare disease that affects several organs and the central nervous system. It is estimated that $61 \%$ of patients with this syndrome are affected by ASD [147]. TSC is caused by mutations in the TSC1 and TSC2 genes, which modulate the mammalian target of rapamycin complex 1 (mTORC), a metabolic sensor [148]. Hippocampal and cortical neurons with a decreased expression of Tsc have less functional mitochondria in the axons, a decline in basal respiration, ATP turnover, total respiratory capacity, and $\Psi_{\mathrm{m}}$, together with mitophagy defects [149]. Similar mitochondrial morphological deficits were found in callosal projection axons in a mouse model of the conditional expression of Tsc1 with synapsin I promoter-driven Cre recombinase allele (Tsc1cc; Syn1-Cre+) [150], which recover a WT-like morphology after treatment with rapamycin [151].

\section{Syndromic ASD caused by 15q11-q13 deletions, microdeletions, and duplications}

The gene encoding ubiquitin-protein ligase E3A $(U B E 3 A)$ is localized to the $15 q 11-15 q 13$ chromosome in humans. UBE3A deficiency is responsible for Angelman syndrome (AS), a severe neurological condition characterized by cognitive impairment and developmental delay. Patients with AS often present with ASD features, although there is an unresolved controversy about considering AS and ASD independent from each other [152]. Increased expression of the Ube $3 a$ gene in mice produced autistic-like behaviors [153]. Additionally, reduced function of complex III in patients with the 15q11-q13 duplication syndrome has been documented [154]. The role of mitochondria has been studied mainly in AS mouse models, like the heterozygous mice Ube $3 a^{m-l p+}$ [155], in which Ube3a was found in close proximity to the outer mitochondrial membrane [156]. Mitochondrial morphological changes in the CA1 hippocampal region were found, like smaller mitochondria and disturbances in mitochondrial cristae compared to WT littermates [157]. Mitochondria were isolated from the hippocampus, cortex, and cerebellum, and the activities of the different components of the electron transport chain (ETC) were tested [158]. A significantly reduced activity of complex III was found in the cortex and hippocampus. Electron flow was recovered by administering a Coenzyme Q10 (CoQ10) analog, increasing the protein expression levels of complexes III and IV in neurons from hippocampal regions $\mathrm{CA} 1, \mathrm{CA} 2$, and $\mathrm{CA} 3$ and the cerebellum. Nonetheless, oxidative stress was decreased only in the hippocampus when measuring the GSH and glutathione disulfide (GSSG) ratio, indicating that this CoQ10 analog influences mainly bioenergetics, and other interventions are necessary to counteract the effects of oxidative stress. In the same AS mouse model, the mitochondrial-targeted antioxidant MitoQ 10-methanesulfonate (MitoQ), which traverses the bloodbrain barrier and accumulates in mitochondria [159], showed promising results by reducing ROS levels in the CA1 hippocampal region and improving synaptic plasticity [160]. A study performed in a mouse model of Prader-Willi syndrome - another neurodevelopmental disorder that displays variable symptomatology and includes ASD in some individuals [161] — found differential expression of 66 mitochondrial genes including those encoding ribosomal proteins 
and the mitochondrial transporter Aralar1 in whole brains [162].

\section{Genetic mutations related to an ASD-like clinical syndrome}

Down syndrome (DS) or trisomy 21 represents a genetic form of mental retardation caused by the overexpression of genes located on chromosome 21, with a high incidence of Alzheimer's disease (AD) [163]. The prevalence of ASD in DS appears to be between 1 and $11 \%$ [164]. The rates vary considerably depending on the sample size and diagnostic criteria employed in each study [165-169]. Additionally, ASD diagnosis is challenging in the DS population due to the intrinsic behavioral and language impairments associated with this syndrome [170]. DS and mitochondrial dysfunction have been assessed in different models, including fibroblasts derived from patients, neuronal cultures derived from fetal tissue, and post-mortem brain tissue of DS individuals [171, 172]. One study explored the role of mitochondria in isolated neural progenitor cells obtained from the dentate gyrus of the well-characterized DS mouse model Ts65Dn [173]. The mitochondria from these cells were more fragmented, showed reduced ATP production, and increased expression of the fission protein Drp1. The mitochondrial phenotype of these cells was reversed by treatment with mitochondrial division inhibitor 1 (Mdivi-1). Mitochondrial functional impairment was also identified in cultured hippocampal neurons and astrocytes from the $T_{s} 1$ Cje DS mouse model, showing reduced $\Psi_{\mathrm{m}}$, decreased ATP levels, and augmented oxidative stress [174]. Antioxidants like epigallocatechin-3-gallate (EGCG) and vitamin E were tested in mouse models of DS [175-177], showing recovered LTP in hippocampal slices and increased neuronal populations in the dentate gyrus of $T s 65 \mathrm{Dn}$ mice, respectively.

Another ASD-associated gene related to mitochondrial function, specifically to mitophagy, is the WD repeat and FYVE domain-containing 3 (WDFY3) [178]. A study published by Napoli et al. used $W d f y 3^{+/ l a c Z}$ mice and obtained mitochondrial-enriched fractions of the whole brain for proteomic analysis [179]. They found altered mitochondrial function in the cortex, cerebellum, and dendrites of primary cortical neurons derived from these mice. Abnormal morphology, budding protrusions, and a significant number of round mitochondria were present. This study also suggested that Wdfy 3 participates in mitochondrial transport and mitophagy. The accumulation of defective mitochondria affects fatty acid $\beta$-oxidation (FAO) and, eventually, neuronal differentiation since FAO controls the shift from neural stem cells to intermediate progenitor cells during brain development in mice [180].

Mitochondrial abnormalities were identified in the inbred $\mathrm{BTBR}+\mathrm{tf} / \mathrm{j}$ (BTBR) mouse line. Isolated mitochondria from the BTBR brain at postnatal day 35 consume less oxygen at basal conditions than controls. Complex II activity was reduced, and a fragmented mitochondrial shape was found in neocortical tissue. The mitochondrial phenotype in this model could be reversed by administering a ketogenic diet (KD) [181]. BTBR mice fed with KD for 14 days showed discrete changes in the mRNA expression of mitochondrial bioenergetic transcripts in the hippocampus and temporal cortex [182]. Another study performed with the BTBR mouse model found that a $\mathrm{KD}$ affects mitochondrial function mainly in the liver, and although an increased gene expression of Fis 1, Drpl, Mff, Opa1, and the gene encoding the BCL2/adenovirus E1B 19kdinteracting protein 3 (Bnip3) in the PFC was found, no significant alterations in protein expression were detected [183].

Mitochondrial respiration using succinate as substrate and the maximal oxygen capacity evaluated after the addition of the mitochondrial uncoupler carbonyl cyanide-ptrifluoromethoxyphenylhydrazone (FCCP) was reduced in isolated mitochondria from the hippocampus of BTBR compared to WT mice [184]. Normal levels of succinate-driven respiration were restored by treatments with antiinflammatory palmitoylethanolamide (PEA). Decreased SOD activity was found in the hippocampus of BTBR mice when assessed spectrophotometrically. The SOD activity was rescued after PEA administration for 10 days.

Many of the studies performed in post-mortem brains of ASD patients provide evidence of mitochondrial abnormalities, both morphological and functional [185]. However, as in many other diseases, it is unknown whether those changes are the consequences of upstream signaling cascades, synaptic impairment, or immunological responses. Mutations in mitochondrial genes have been postulated to confer ASD vulnerability, like SLC25A12, which codes for the isoform 1 of the $\mathrm{Ca}^{2+}$ regulated mitochondrial aspartate-glutamate carrier Aralar (Aralar1) [186]. Nevertheless, ASD susceptibility conferred by the $S L C 25 \mathrm{~A} 12$ gene is only present in specific populations.

Another gene of the solute carrier family associated with autism is SLC7A11 [187]. The SLC7A11 gene codes for XCT, a subunit of the astrocytic cystine-glutamate antiporter system (xc-). This transport system is necessary for redox balance and regulation of extracellular glutamate concentrations [188] by cooperating with excitatory glutamate transporters [189]. The deletion of $\mathrm{xCT}$ in mice produced less presynaptic mitochondria in the dorsolateral striatum and behavioral deficits associated with ASD [190]. This study highlights the significant role of astrocytes in ASD. The mitochondrial proteome composition differs according to brain cell type, showing differences in beta-oxidation between neurons and astrocytes [191].

GABAergic neurons that contain parvalbumin (PV+) are of particular interest in ASD $[192,193]$. PV binds $\mathrm{Ca}^{2+}$ through EF-hand domains and participates in buffering intracellular $\left[\mathrm{Ca}^{2+}\right]$ [194-196]. The absence of PV in mice recapitulates ASD features, and a recent study showed that mitochondrial 
Table 1 Mitochondrial disturbances found in specific brain regions of ASD and ASD-related neurodevelopmental disease mouse models

\begin{tabular}{lll}
\hline Author & Mitochondrial disturbances & Model \\
\hline
\end{tabular}

Bekay et. al

2007 [107]

Kaplan et. al 2012

$$
\text { [108] }
$$

Napoli et. al

2016 [110]

D'Antoni et. al 2019

Shen et. al 2019

[109]

Griffiths et. al

2020 [114]

Kuzniewska et. al 2020 [115]

Devaraju et. al 2017

Fernandez et. al 201

[122]

Gokhale et. al 2019 Mitochondrial proteome affected

[123]

Kriaucionis et. al Increased respiration 2006 [145]

Urdinguio et. al 2008 Increased expression of Prodh [139]

Belichenko et. al Increased elongated mitochondria 2009 [128]

Forlani et. al $2010 \quad$ Increased expression of Slc25a4

$$
\text { [136] }
$$

Grosser et. al

2012 [129]

DeFelice et. al

2014 [130]

Janc et. al

2014 [131]

Jin et. al 2015 [135]

DeFilippis et.al, 2015 [141]

DeFilippis et.al, 2015 [142]

Bebensee et. al 2017 [132]

Valenti et. al

2017 [143]

Can et. al

2019 [144]

Zuliani et. al

2020 [133]

Dave et. al 2020 [134]

Ebrahimi-Fakhari et. al 2016 [149]

Su et. al 2011 [157] unction ATPB respiration synapse production

Increased oxidative stress cerebellum, cerebellum oxidative stress ROS production increased oxidative stress
Higher levels of ROS, NADPH oxidase activation, Fmrl-KO mice altered expression levels of the GSH system

Decreased number, mobility, and metabolic

Lower ATP production and lower expression of

, lower ATP production in cortex reduced mitochondrial $\mathrm{Ca}^{2+}$ uptake

Abnormal mitochondrial morphology, increased

mpaired STP and mitochondrial buffering in the

Increased SOD1 expression, increased ROS

Decreased FAD/NADH ratio, reduced $\Psi_{\mathrm{m}}$

Increased oxygen consumption, reduced ATP production, overexpression of Snat1

Reduced activity of complexes II, III, IV, and V

Increased ROS and diminished ATP production in Mecp2-308 mice mitochondria isolated from whole brain and

Reduced activity of complexes I, II, and V in mitochondria isolated from striatum and

Augmented mitochondrial number, increased

Reduced ATP production and ATP concentration, Mecp2-308 mice reduced activities of ETC complexes, increased

Increased ROS, intensified oxygen consumption

Reduced ATP production, reduced activities of mitochondrial complexes II and V, decreased protein expression of ETC complexes,

Reduced activities of ETC complexes, reduced $\Psi_{\mathrm{m}} \quad$ Mecp2-KO astrocytes

Accumulation of mitochondria in the cell bodies, decreased $\Psi_{\mathrm{m}}$, decreased baseline respiration, ATP and total respiratory capacity Impaired morphology, decreased activity of complex III
Premutation

Fmrl-KI mice

Premutation

Fmr1-KI mice

Fmrl-KO mice

Fmr1-KO mice

Fmrl-KO mice

Fmrl-KO mice

$\mathrm{Mrpl}_{40}^{+/-}$mice

LgDel $22 q 11$ mice

$D f(16) A^{+/}$mice

Mecp2-KO mice

Mecp2-KO mice

$\operatorname{Mecp} 2 B$ mice

Mecp2-KO mice

Mecp2-308 mice

Mecp2-KO and

Меср2-308 mice

Mecp2-KO mice

Mecp2-KO mice

Mecp2-308 mice

Mecp2-KO mice

Mecp2-KO mice

Mecp2-308 mice

Tsclcc; Syn1-Cre+ mice, iPSC-derived cortical neurons

Ube3am- $\mid p+$ mice
Hippocampus, PFC, cortex, cerebellum

Primary hippocampal neurons

Hippocampus

Cortex, striatum, cerebellum

Primary hippocampal neurons

Isolated mitochondria from forebrain

Synaptic mitochondria

CA3 hippocampal region

Cortex (layer 2/3)

Hippocampus, PFC

Mitochondria isolated from whole brains

Cortex, cerebellum

Hippocampus

Whole brain, cerebellum

Hippocampus

Whole brain

CA1 hippocampal region

Microglia

Mitochondria isolated from hippocampus and cortex

Mitochondria from whole brain, striatum, and cerebellum

Primary hippocampal astrocytes

Mitochondria isolated from whole brain

Hippocampus, cortex

Whole brain

Primary cultured astrocytes

Hippocampal and cortical neurons, iPSC-derived cortical neurons from TSC patients

CA1 hippocampal regions, hippocampus 
Table 1 (continued)

\begin{tabular}{|c|c|c|c|}
\hline Author & Mitochondrial disturbances & Model & Brain regions evaluated \\
\hline $\begin{array}{l}\text { Yazdi et. al } 2013 \\
{[162]}\end{array}$ & Differential expression of mitochondrial genes & PWS-IC del mice & Whole brain \\
\hline $\begin{array}{l}\text { Santini et. al } \\
2015[160]\end{array}$ & Enhanced levels of superoxide & $\begin{array}{l}\text { Ube } 3 a m-\mid p+ \\
\text { mice }\end{array}$ & $\begin{array}{l}\text { Hippocampal and cerebellar acute slices } \\
\text { Hippocampus }\end{array}$ \\
\hline $\begin{array}{l}\text { Llewellyn et. al } 2015 \\
\quad[158]\end{array}$ & $\begin{array}{l}\text { Reduced activity of complex III, increased } \\
\text { oxidative stress }\end{array}$ & $\begin{array}{l}\text { Ube3am- } \mid p+ \\
\text { mice }\end{array}$ & Cortex, hippocampus \\
\hline $\begin{array}{l}\text { Shukkur et. al } \\
2006[174]\end{array}$ & $\begin{array}{l}\text { Decreased } \Psi_{\mathrm{m}} \text {, decreased ATP production, } \\
\text { increased oxidative stress }\end{array}$ & Ts1Cje mice & $\begin{array}{l}\text { Hippocampal neurons } \\
\text { Dentate Gyrus }\end{array}$ \\
\hline $\begin{array}{l}\text { Valenti et. al } \\
2017[173]\end{array}$ & $\begin{array}{l}\text { Fragmented morphology, decreased ATP } \\
\text { production, increased expression of Drp1 }\end{array}$ & Ts65Dn mice & Dentate Gyrus \\
\hline $\begin{array}{l}\text { Napoli et. al } 2018 \\
\text { [179] }\end{array}$ & $\begin{array}{l}\text { Lower ATP production, decreased cristae density, } \\
\text { reduced OXPHOS capacity, increased ROS, } \\
\text { increased proton leak }\end{array}$ & $\begin{array}{l}\text { Wdfy3- } \\
\text { haploinsufficient } \\
\text { mice }\end{array}$ & Cortex, hippocampus, cerebellum (most affected) \\
\hline $\begin{array}{l}\text { Newell et. al } \\
2016[183]\end{array}$ & $\begin{array}{l}\text { Increased expression of genes associated with } \\
\text { mitochondrial fission/fusion after administra- } \\
\text { tion of KD } \\
\text { Increased expression of Bnip3 }\end{array}$ & BTBR mice & $\mathrm{PFC}$ \\
\hline $\begin{array}{l}\text { Mychasiuk et. al } \\
2017 \\
{[182]}\end{array}$ & $\begin{array}{l}\text { Changes in expression of mitochondrial } \\
\text { bioenergetics genes after administration of } \mathrm{KD}\end{array}$ & BTBR mice & $\begin{array}{l}\text { Isolated mitochondria from hippocampus and } \\
\text { cortex }\end{array}$ \\
\hline $\begin{array}{l}\text { Cristiano et. al } \\
2018 \text { [184] }\end{array}$ & $\begin{array}{l}\text { Reduced oxygen consumption, reduced SOD } \\
\text { activity, increased ROS production }\end{array}$ & BTBR mice & $\begin{array}{l}\text { Isolated mitochondria from hippocampus, } \\
\text { hippocampus }\end{array}$ \\
\hline $\begin{array}{l}\text { Ahn et. al } \\
2020[181]\end{array}$ & $\begin{array}{l}\text { Reduced oxygen consumption, round shape } \\
\text { mitochondria, increased expression of } \\
\text { phosho-Drp1 at Ser616 and phospho-Mff at } \\
\text { Ser146 }\end{array}$ & BTBR mice & $\begin{array}{l}\text { Isolated mitochondria from Neocortex, primary } \\
\text { cortical neurons }\end{array}$ \\
\hline $\begin{array}{l}\text { Bentea et. al } 2020 \\
\quad[190]\end{array}$ & Reduced presynaptic mitochondrial population & $x C T^{/-}$mice & Striatum \\
\hline $\begin{array}{l}\text { Janickova et. al } \\
2020[197]\end{array}$ & Increased mitochondrial volume/density & PV-deficient mice & $\begin{array}{l}\text { Neurons from the striatum, the medial PFC, the } \\
\text { somatosensory cortex, the thalamic reticular } \\
\text { nucleus, Purkinje neurons, molecular layer } \\
\text { interneurons }\end{array}$ \\
\hline
\end{tabular}

morphology is affected in this model, showing increased density and volume in the soma of neurons from the striatum, the medial PFC, the somatosensory cortex, the thalamic reticular nucleus, Purkinje neurons, and molecular layer interneurons [197]. Table 1 and Fig. 3 summarize the mitochondrial defects found in different brain regions and the models involved.

\section{Concluding remarks}

The complexity of ASD is characterized by mitochondrial dysfunction, among other factors. Evidence for the involvement of mitochondria in ASD is increasing and has been tested in multiple models [198-202]. Mitochondrial disease also co-occurs with ASD and is sometimes difficult to distinguish [203]. However, no precise biological mechanisms are available to explain mitochondrial dysfunction and ASD, and studies directed to evaluate the efficacy of mitochondrial-targeted compounds in patients are scarce [204].
Currently, it is widely accepted that mitochondrial function varies in different parts of the brain $[205,206]$ and their role at the synapse goes beyond providing energy and stabilizing $\mathrm{Ca}^{2+}$ concentrations [207]. Studies focusing on mitochondria at the synapse are necessary to distinguish their role between the preand postsynapse in ASD and ASD-related neurodevelopmental disorders. Although most of the studies have focused on hippocampal mitochondria, the cerebellum and the cortex have a distinctive mitochondrial phenotype that can contribute to the variability of the symptoms observed in patients. Other mitochondrial populations need to be studied, like the ones from the amygdala and striatum, brain regions that participate in the conceptualization and execution of emotions, memory, learning habits, and motor skills [208, 209]. For example, the striatum has a higher OXPHOS activity than the hippocampus and cortex and is especially sensitive to $\mathrm{Ca}^{2+}$ overload [210, 211]. Understanding how synaptic mitochondria contribute to different neuronal populations in disease states could help to elucidate and develop novel therapeutic options to treat ASD and ASD-related neurodevelopmental disorders more effectively. 
a

$\downarrow$ ATP production

$\uparrow$ NADPH oxidase
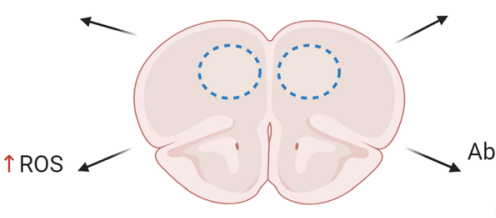

sence of cristae in layer $2 / 3$

(in the LgDel22q71 model)

\begin{tabular}{|c|}
\hline Fmr1 \\
Mecp2 \\
Wdfy3- \\
LgDel22q11 \\
\hline
\end{tabular}

C

Hippocampus

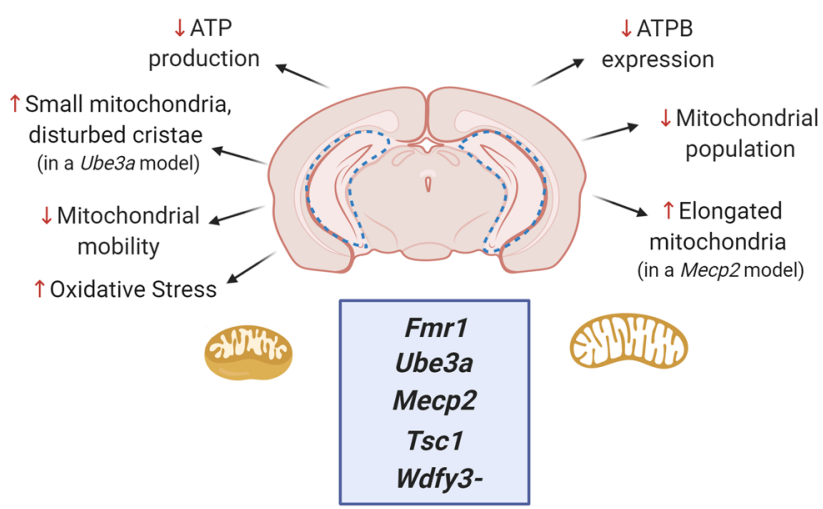

Fig. 3 Mitochondrial disturbances in different brain regions of mouse models of ASD. The figure provides an overview of the mitochondrial defects found in the cortex/prefrontal cortex (PFC), striatum, hippocampus, and cerebellum in different ASD mouse models. Arrows point to the specific mitochondrial disturbances found in the different mouse models

Authors' contributions Conceptualization: L.R-C., A.M., M.J.S.; creation of figures: L.R.-C., L.N.; writing: L.R.-C., A.M., M.J.S.

Funding Open Access funding enabled and organized by Projekt DEAL. L.R.-C. holds a scholarship of the Focus Program of Translational Neurosciences (FTN) at the University Medical Center of the Johannes Gutenberg University Mainz. M.J.S. was supported by the Care for Rare Foundation, the Eva Luise and Horst Köhler Foundation, the Else Kröner Fresenius Foundation (2018_A78), the Volkswagen Foundation and the German Ministry of Education and Research (BMBF) (GeNeRARe; 01GM1519A). A.M. was funded by the Deutsche Forschungsgemeinschaft DFG ME1922/14-1.

\section{Compliance with ethical standards}

Conflict of interest The authors declare that they have no conflict of interest.

Ethics approval Not applicable.

Consent to participate Not applicable. b

Striatum

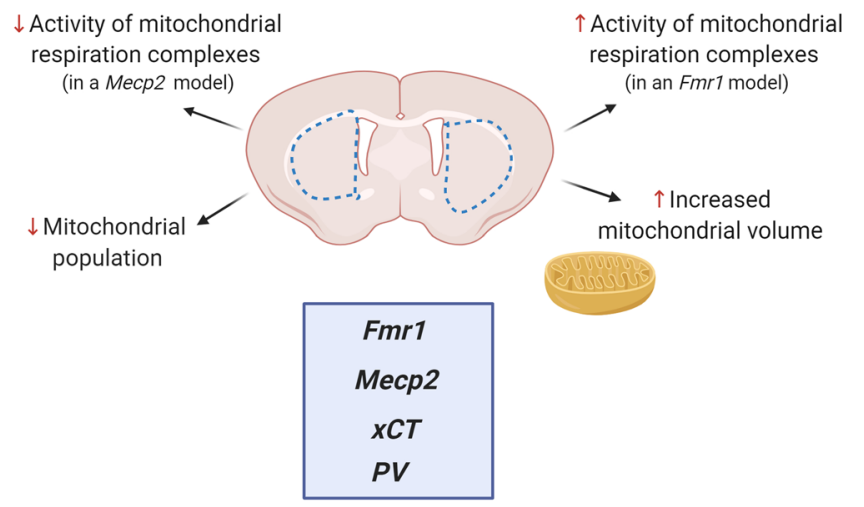

d

Cerebellum

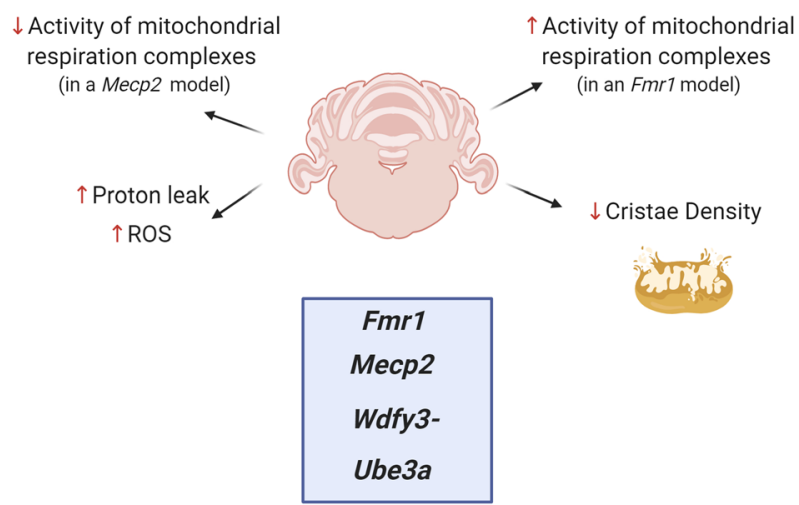

in a cortex and PFC; $\mathbf{b}$ striatum; $\mathbf{c}$ hippocampus and $\mathbf{d}$ cerebellum. Dotted blue lines delineate the specific brain regions. Most of the studies are focused on hippocampal mitochondria; the mitochondrial phenotype has been most extensively studied in Fmrl and Mecp2 mutant mouse models. Created with BioRender.com

Open Access This article is licensed under a Creative Commons Attribution 4.0 International License, which permits use, sharing, adaptation, distribution and reproduction in any medium or format, as long as you give appropriate credit to the original author(s) and the source, provide a link to the Creative Commons licence, and indicate if changes were made. The images or other third party material in this article are included in the article's Creative Commons licence, unless indicated otherwise in a credit line to the material. If material is not included in the article's Creative Commons licence and your intended use is not permitted by statutory regulation or exceeds the permitted use, you will need to obtain permission directly from the copyright holder. To view a copy of this licence, visit http://creativecommons.org/licenses/by/4.0/.

\section{References}

1. Muhle RA, Reed HE, Stratigos KA, Veenstra-VanderWeele J (2018) The emerging clinical neuroscience of autism spectrum disorder: a review. JAMA Psychiatry 75(5):514-523 
2. Bagni C, Zukin RS (2019) A synaptic perspective of fragile X syndrome and autism spectrum disorders. Neuron 101(6):1070 1088

3. Bourgeron $\mathrm{T}$ (2015) From the genetic architecture to synaptic plasticity in autism spectrum disorder. Nat Rev Neurosci 16(9): 551-563

4. de la Torre-Ubieta L, Won H, Stein JL, Geschwind DH (2016) Advancing the understanding of autism disease mechanisms through genetics. Nat Med 22(4):345-361

5. Varghese M, Keshav N, Jacot-Descombes S, Warda T, Wicinski B, Dickstein DL, Harony-Nicolas H, De Rubeis S, Drapeau E, Buxbaum JD, Hof PR (2017) Autism spectrum disorder: neuropathology and animal models. Acta Neuropathol 134(4):537-566

6. Kleijer KT, Schmeisser MJ, Krueger DD, Boeckers TM, Scheiffele P, Bourgeron T, Brose N, Burbach JP (2014) Neurobiology of autism gene products: towards pathogenesis and drug targets. Psychopharmacology 231(6):1037-1062

7. Grabrucker AM, Schmeisser MJ, Schoen M, Boeckers TM (2011) Postsynaptic ProSAP/Shank scaffolds in the cross-hair of synaptopathies. Trends Cell Biol 21(10):594-603

8. Hall CN, Klein-Flugge MC, Howarth C, Attwell D (2012) Oxidative phosphorylation, not glycolysis, powers presynaptic and postsynaptic mechanisms underlying brain information processing. J Neurosci 32(26):8940-8951

9. Smith HL, Bourne JN, Cao G, Chirillo MA, Ostroff LE, Watson DJ, Harris KM (2016) Mitochondrial support of persistent presynaptic vesicle mobilization with age-dependent synaptic growth after LTP. Elife 5:e15275

10. Delgado T, Petralia RS, Freeman DW, Sedlacek M, Wang YX, Brenowitz SD, Sheu SH, Gu JW, Kapogiannis D, Mattson MP, Yao PJ (2019) Comparing 3D ultrastructure of presynaptic and postsynaptic mitochondria. Biol Open 8(8):bio044834

11. Fischer TD, Dash PK, Liu J, Waxham MN (2018) Morphology of mitochondria in spatially restricted axons revealed by cryoelectron tomography. PLoS Biol 16(9):e2006169

12. Rangaraju V, Lauterbach M, Schuman EM (2019) Spatially stable mitochondrial compartments fuel local translation during plasticity. Cell 176(1-2):73-84 e15

13. Devine MJ, Kittler JT (2018) Mitochondria at the neuronal presynapse in health and disease. Nat Rev Neurosci 19(2):63-80

14. Todorova V, Blokland A (2017) Mitochondria and synaptic plasticity in the mature and aging nervous system. Curr Neuropharmacol 15(1):166-173

15. Zenisek D, Matthews G (2000) The role of mitochondria in presynaptic calcium handling at a ribbon synapse. Neuron 25(1):229 237

16. Bell M, Bartol T, Sejnowski T, Rangamani P (2019) Dendritic spine geometry and spine apparatus organization govern the spatiotemporal dynamics of calcium. J Gen Physiol 151(8):10171034

17. Marland JR, Hasel P, Bonnycastle K, Cousin MA (2016) Mitochondrial calcium uptake modulates synaptic vesicle endocytosis in central nerve terminals. J Biol Chem 291(5):2080-2086

18. Gazit N, Vertkin I, Shapira I, Helm M, Slomowitz E, Sheiba M, Mor Y, Rizzoli S, Slutsky I (2016) IGF-1 receptor differentially regulates spontaneous and evoked transmission via mitochondria at hippocampal synapses. Neuron 89(3):583-597

19. Kwon SK, Sando R 3rd, Lewis TL, Hirabayashi Y, Maximov A, Polleux F (2016) LKB1 regulates mitochondria-dependent presynaptic calcium clearance and neurotransmitter release properties at excitatory synapses along cortical axons. PLoS Biol 14(7): e1002516

20. Harris JJ, Jolivet R, Attwell D (2012) Synaptic energy use and supply. Neuron 75(5):762-777
21. Kwon SK, Hirabayashi Y, Polleux F (2016) Organelle-specific sensors for monitoring $\mathrm{Ca}(2+)$ dynamics in neurons. Front Synaptic Neurosci 8:29

22. Ly CV, Verstreken P (2006) Mitochondria at the synapse. Neuroscientist 12(4):291-299

23. Rizzuto R, Pinton P, Carrington W, Fay FS, Fogarty KE, Lifshitz LM, Tuft RA, Pozzan T (1998) Close contacts with the endoplasmic reticulum as determinants of mitochondrial $\mathrm{Ca} 2+$ responses. Science 280(5370): 1763-1766

24. Krols M, Bultynck G, Janssens S (2016) ER-Mitochondria contact sites: a new regulator of cellular calcium flux comes into play. J Cell Biol 214(4):367-370

25. Hayashi T, Su TP (2007) Sigma-1 receptor chaperones at the ERmitochondrion interface regulate $\mathrm{Ca}(2+)$ signaling and cell survival. Cell 131(3):596-610

26. De Vos KJ, Morotz GM, Stoica R, Tudor EL, Lau KF, Ackerley S, Warley A, Shaw CE, Miller CC (2012) VAPB interacts with the mitochondrial protein PTPIP51 to regulate calcium homeostasis. Hum Mol Genet 21(6):1299-1311

27. Teuling E, Ahmed S, Haasdijk E, Demmers J, Steinmetz MO, Akhmanova A, Jaarsma D, Hoogenraad CC (2007) Motor neuron disease-associated mutant vesicle-associated membrane proteinassociated protein (VAP) B recruits wild-type VAPs into endoplasmic reticulum-derived tubular aggregates. J Neurosci 27(36): 9801-9815

28. Christ MG, Clement AM, Behl C (2020) The Sigma-1 receptor at the crossroad of proteostasis, neurodegeneration, and autophagy. Trends Neurosci 43(2):79-81

29. Gomez-Suaga P, Perez-Nievas BG, Glennon EB, Lau DHW, Paillusson S, Morotz GM, Cali T, Pizzo P, Noble W, Miller CCJ (2019) The VAPB-PTPIP51 endoplasmic reticulummitochondria tethering proteins are present in neuronal synapses and regulate synaptic activity. Acta Neuropathol Commun 7(1):35

30. Lee S, Min KT (2018) The interface between ER and mitochondria: molecular compositions and functions. Mol Cell 41(12): $1000-1007$

31. Denton RM, Randle PJ, Martin BR (1972) Stimulation by calcium ions of pyruvate dehydrogenase phosphate phosphatase. Biochem J 128(1):161-163

32. Denton RM, Richards DA, Chin JG (1978) Calcium ions and the regulation of NAD+-linked isocitrate dehydrogenase from the mitochondria of rat heart and other tissues. Biochem J 176(3):899906

33. Scaduto RC Jr (1994) Calcium and 2-oxoglutarate-mediated control of aspartate formation by rat heart mitochondria. Eur $\mathrm{J}$ Biochem 223(3):751-758

34. Ryu SY, Beutner G, Dirksen RT, Kinnally KW, Sheu SS (2010) Mitochondrial ryanodine receptors and other mitochondrial $\mathrm{Ca} 2+$ permeable channels. FEBS Lett 584(10):1948-1955

35. Gunter TE, Sheu SS (2009) Characteristics and possible functions of mitochondrial $\mathrm{Ca}(2+)$ transport mechanisms. Biochim Biophys Acta 1787(11):1291-1308

36. Jakob R, Beutner G, Sharma VK, Duan Y, Gross RA, Hurst S, Jhun BS, O-Uchi J, Sheu SS (2014) Molecular and functional identification of a mitochondrial ryanodine receptor in neurons. Neurosci Lett 575:7-12

37. Takeuchi A, Kim B, Matsuoka S (2015) The destiny of Ca(2+) released by mitochondria. J Physiol Sci 65(1):11-24

38. Giorgi C, Marchi S, Pinton P (2018) The machineries, regulation and cellular functions of mitochondrial calcium. Nat Rev Mol Cell Biol 19(11):713-730

39. Vos M, Lauwers E, Verstreken P (2010) Synaptic mitochondria in synaptic transmission and organization of vesicle pools in health and disease. Front Synaptic Neurosci 2:139

40. Filadi R, Pendin D, Pizzo P (2018) Mitofusin 2: from functions to disease. Cell Death Dis 9(3):330 
41. Iwasawa R, Mahul-Mellier AL, Datler C, Pazarentzos E, Grimm S (2011) Fis1 and Bap31 bridge the mitochondria-ER interface to establish a platform for apoptosis induction. EMBO J 30(3):556568

42. Baker MR, Fan G, Serysheva II (2017) Structure of IP3R channel: high-resolution insights from cryo-EM. Curr Opin Struct Biol 46: $38-47$

43. Fedorovich SV, Waseem TV, Puchkova LV (2017) Biogenetic and morphofunctional heterogeneity of mitochondria: the case of synaptic mitochondria. Rev Neurosci 28(4):363-373

44. Barnhart EL (2016) Mechanics of mitochondrial motility in neurons. Curr Opin Cell Biol 38:90-99

45. Youle RJ, Karbowski M (2005) Mitochondrial fission in apoptosis. Nat Rev Mol Cell Biol 6(8):657-663

46. Barel O, Malicdan MCV, Ben-Zeev B, Kandel J, Pri-Chen H, Stephen J, Castro IG, Metz J, Atawa O, Moshkovitz S, Ganelin E, Barshack I, Polak-Charcon S et al (2017) Deleterious variants in TRAK1 disrupt mitochondrial movement and cause fatal encephalopathy. Brain 140(3):568-581

47. Nasca A, Nardecchia F, Commone A, Semeraro M, Legati A, Garavaglia B, Ghezzi D, Leuzzi V (2018) Clinical and biochemical features in a patient with mitochondrial fission factor gene alteration. Front Genet 9:625

48. Yu-Wai-Man P, Griffiths PG, Gorman GS, Lourenco CM, Wright AF, Auer-Grumbach M, Toscano A, Musumeci O, Valentino ML, Caporali L, Lamperti C, Tallaksen CM et al (2010) Multi-system neurological disease is common in patients with OPA1 mutations. Brain 133(Pt 3):771-786

49. Chen H, Chan DC (2010) Physiological functions of mitochondrial fusion. Ann N Y Acad Sci 1201:21-25

50. Escobar-Henriques M, Joaquim M (2019) Mitofusins: disease gatekeepers and hubs in mitochondrial quality control by E3 ligases. Front Physiol 10:517

51. Quintana-Cabrera R, Quirin C, Glytsou C, Corrado M, Urbani A, Pellattiero A, Calvo E, Vazquez J, Enriquez JA, Gerle C, Soriano ME, Bernardi P, Scorrano L (2018) The cristae modulator optic atrophy 1 requires mitochondrial ATP synthase oligomers to safeguard mitochondrial function. Nat Commun 9(1):3399

52. Jiang S, Nandy P, Wang W, Ma X, Hsia J, Wang C, Wang Z, Niu M, Siedlak SL, Torres S, Fujioka H, Xu Y, Lee HG, Perry G, Liu J, Zhu X (2018) Mfn2 ablation causes an oxidative stress response and eventual neuronal death in the hippocampus and cortex. Mol Neurodegener 13(1):5

53. de Brito OM, Scorrano L (2008) Mitofusin 2 tethers endoplasmic reticulum to mitochondria. Nature 456(7222):605-610

54. Bernard-Marissal N, van Hameren G, Juneja M, Pellegrino C, Louhivuori L, Bartesaghi L, Rochat C, El Mansour O, Medard JJ, Croisier M, Maclachlan C, Poirot O, Uhlen P, Timmerman V, Tricaud N, Schneider BL, Chrast R (2019) Altered interplay between endoplasmic reticulum and mitochondria in Charcot-MarieTooth type 2A neuropathy. Proc Natl Acad Sci U S A 116(6): 2328-2337

55. Fowler PC, Garcia-Pardo ME, Simpson JC, O’Sullivan NC (2019) NeurodegenERation: the central role for er contacts in neuronal function and axonopathy, lessons from hereditary spastic paraplegias and related diseases. Front Neurosci 13:105

56. Tilokani L, Nagashima S, Paupe V, Prudent J (2018) Mitochondrial dynamics: overview of molecular mechanisms. Essays Biochem 62(3):341-360

57. Chang CR, Blackstone C (2010) Dynamic regulation of mitochondrial fission through modification of the dynamin-related protein Drp1. Ann N Y Acad Sci 1201:34-39

58. Flippo KH, Strack S (2017) Mitochondrial dynamics in neuronal injury, development and plasticity. J Cell Sci 130(4):671-681
59. Lee DS, Kim JE (2018) PDI-mediated S-nitrosylation of DRP1 facilitates DRP1-S616 phosphorylation and mitochondrial fission in CA1 neurons. Cell Death Dis 9(9):869

60. Wolf C, Lopez Del Amo V, Arndt S, Bueno D, Tenzer S, Hanschmann EM, Berndt C, Methner A (2020) Redox modifications of proteins of the mitochondrial fusion and fission machinery. Cells 9(4):815

61. Cagalinec M, Safiulina D, Liiv M, Liiv J, Choubey V, Wareski P, Veksler V, Kaasik A (2013) Principles of the mitochondrial fusion and fission cycle in neurons. J Cell Sci 126(Pt 10):2187-2197

62. Oettinghaus B, Schulz JM, Restelli LM, Licci M, Savoia C, Schmidt A, Schmitt K, Grimm A, More L, Hench J, Tolnay M, Eckert A, D'Adamo P, Franken P, Ishihara N, Mihara K, Bischofberger J, Scorrano L, Frank S (2016) Synaptic dysfunction, memory deficits and hippocampal atrophy due to ablation of mitochondrial fission in adult forebrain neurons. Cell Death Differ 23(1): $18-28$

63. Shields LY, Kim H, Zhu L, Haddad D, Berthet A, Pathak D, Lam M, Ponnusamy R, Diaz-Ramirez LG, Gill TM, Sesaki H, Mucke L, Nakamura K (2015) Dynamin-related protein 1 is required for normal mitochondrial bioenergetic and synaptic function in CA1 hippocampal neurons. Cell Death Dis 6:e1725

64. Divakaruni SS, Van Dyke AM, Chandra R, LeGates TA, Contreras M, Dharmasri PA, Higgs HN, Lobo MK, Thompson SM, Blanpied TA (2018) Long-term potentiation requires a rapid burst of dendritic mitochondrial fission during induction. Neuron 100(4):860-875 e867

65. Godoy JA, Arrazola MS, Ordenes D, Silva-Alvarez C, Braidy N, Inestrosa NC (2014) Wnt-5a ligand modulates mitochondrial fission-fusion in rat hippocampal neurons. J Biol Chem 289(52): 36179-36193

66. Lewis TL Jr, Kwon SK, Lee A, Shaw R, Polleux F (2018) MFFdependent mitochondrial fission regulates presynaptic release and axon branching by limiting axonal mitochondria size. Nat Commun 9(1):5008

67. Ashrafi G, Schlehe JS, LaVoie MJ, Schwarz TL (2014) Mitophagy of damaged mitochondria occurs locally in distal neuronal axons and requires PINK1 and Parkin. J Cell Biol 206(5): 655-670

68. McWilliams TG, Prescott AR, Allen GF, Tamjar J, Munson MJ, Thomson C, Muqit MM, Ganley IG (2016) mito-QC illuminates mitophagy and mitochondrial architecture in vivo. J Cell Biol 214(3):333-345

69. Cai Q, Zakaria HM, Simone A, Sheng ZH (2012) Spatial parkin translocation and degradation of damaged mitochondria via mitophagy in live cortical neurons. Curr Biol 22(6):545-552

70. Pickles S, Vigie P, Youle RJ (2018) Mitophagy and quality control mechanisms in mitochondrial maintenance. Curr Biol 28(4): R170-R185

71. Koyano F, Okatsu K, Kosako H, Tamura Y, Go E, Kimura M, Kimura Y, Tsuchiya H, Yoshihara H, Hirokawa T, Endo T, Fon EA, Trempe JF, Saeki Y, Tanaka K, Matsuda N (2014) Ubiquitin is phosphorylated by PINK1 to activate parkin. Nature 510(7503): $162-166$

72. Martinez-Vicente M (2017) Neuronal mitophagy in neurodegenerative diseases. Front Mol Neurosci 10:64

73. Evans CS, Holzbaur EL (2020) Degradation of engulfed mitochondria is rate-limiting in Optineurin-mediated mitophagy in neurons. Elife 9:e50260

74. Evans CS, Holzbaur ELF (2020) Quality control in neurons: mitophagy and other selective autophagy mechanisms. J Mol Biol 432(1):240-260

75. McWilliams TG, Prescott AR, Montava-Garriga L, Ball G, Singh F, Barini E, Muqit MMK, Brooks SP, Ganley IG (2018) Basal mitophagy occurs independently of PINK1 in mouse tissues of high metabolic demand. Cell Metab 27(2):439-449 e435 
76. Li S, Xiong GJ, Huang N, Sheng ZH (2020) The cross-talk of energy sensing and mitochondrial anchoring sustains synaptic efficacy by maintaining presynaptic metabolism. Nature Metabolism 2(10):1077-1095

77. Cai Q, Davis ML, Sheng ZH (2011) Regulation of axonal mitochondrial transport and its impact on synaptic transmission. Neurosci Res 70(1):9-15

78. Li Z, Okamoto K, Hayashi Y, Sheng M (2004) The importance of dendritic mitochondria in the morphogenesis and plasticity of spines and synapses. Cell 119(6):873-887

79. van Spronsen M, Mikhaylova M, Lipka J, Schlager MA, van den Heuvel DJ, Kuijpers M, Wulf PS, Keijzer N, Demmers J, Kapitein LC, Jaarsma D, Gerritsen HC, Akhmanova A, Hoogenraad CC (2013) TRAK/Milton motor-adaptor proteins steer mitochondrial trafficking to axons and dendrites. Neuron 77(3):485-502

80. Mandal A, Drerup CM (2019) Axonal transport and mitochondrial function in neurons. Front Cell Neurosci 13:373

81. Saxton WM, Hollenbeck PJ (2012) The axonal transport of mitochondria. J Cell Sci 125(Pt 9):2095-2104

82. Chen Y, Sheng ZH (2013) Kinesin-1-syntaphilin coupling mediates activity-dependent regulation of axonal mitochondrial transport. J Cell Biol 202(2):351-364

83. Lin MY, Cheng XT, Tammineni P, Xie Y, Zhou B, Cai Q, Sheng ZH (2017) Releasing syntaphilin removes stressed mitochondria from axons independent of mitophagy under pathophysiological conditions. Neuron 94(3):595-610 e596

84. Faits MC, Zhang C, Soto F, Kerschensteiner D (2016) Dendritic mitochondria reach stable positions during circuit development. Elife 5:e11583

85. Sheng M, Hoogenraad CC (2007) The postsynaptic architecture of excitatory synapses: a more quantitative view. Annu Rev Biochem 76:823-847

86. Freeman DW, Petralia RS, Wang YX, Mattson MP, Yao PJ (2017) Mitochondria in hippocampal presynaptic and postsynaptic compartments differ in size as well as intensity. Matters (Zur). https://doi.org/10.19185/matters.201711000009

87. Hedskog L, Pinho CM, Filadi R, Ronnback A, Hertwig L, Wiehager B, Larssen P, Gellhaar S, Sandebring A, Westerlund M, Graff C, Winblad B, Galter D, Behbahani H, Pizzo P, Glaser E, Ankarcrona M (2013) Modulation of the endoplasmic reticulum-mitochondria interface in Alzheimer's disease and related models. Proc Natl Acad Sci U S A 110(19):7916-7921

88. Chang DT, Honick AS, Reynolds IJ (2006) Mitochondrial trafficking to synapses in cultured primary cortical neurons. J Neurosci 26(26):7035-7045

89. Cserep C, Posfai B, Schwarcz AD, Denes A (2018) Mitochondrial ultrastructure is coupled to synaptic performance at axonal release sites. eNeuro 5(1):ENEURO.0390-17.2018

90. Lisman JE, Raghavachari S, Tsien RW (2007) The sequence of events that underlie quantal transmission at central glutamatergic synapses. Nat Rev Neurosci 8(8):597-609

91. Sudhof TC (2008) Neuroligins and neurexins link synaptic function to cognitive disease. Nature 455(7215):903-911

92. Kayser MA (2008) Inherited metabolic diseases in neurodevelopmental and neurobehavioral disorders. Semin Pediatr Neurol 15(3):127-131

93. Saudubray JM, Garcia-Cazorla A (2018) An overview of inborn errors of metabolism affecting the brain: from neurodevelopment to neurodegenerative disorders. Dialogues Clin Neurosci 20(4): 301-325

94. Monteiro P, Feng G (2017) SHANK proteins: roles at the synapse and in autism spectrum disorder. Nat Rev Neurosci 18(3):147157

95. Reim D, Distler U, Halbedl S, Verpelli C, Sala C, Bockmann J, Tenzer S, Boeckers TM, Schmeisser MJ (2017) Proteomic analysis of post-synaptic density fractions from Shank 3 mutant mice reveals brain region specific changes relevant to autism spectrum disorder. Front Mol Neurosci 10:26

96. Vicidomini C, Ponzoni L, Lim D, Schmeisser MJ, Reim D, Morello N, Orellana D, Tozzi A, Durante V, Scalmani P, Mantegazza M, Genazzani AA, Giustetto M, Sala M, Calabresi P, Boeckers TM, Sala C, Verpelli C (2017) Pharmacological enhancement of mGlu5 receptors rescues behavioral deficits in SHANK3 knock-out mice. Mol Psychiatry 22(5):784

97. Peter S, Ten Brinke MM, Stedehouder J, Reinelt CM, Wu B, Zhou H, Zhou K, Boele HJ, Kushner SA, Lee MG, Schmeisser MJ, Boeckers TM, Schonewille M, Hoebeek FE, De Zeeuw CI (2016) Dysfunctional cerebellar Purkinje cells contribute to autism-like behaviour in Shank2-deficient mice. Nat Commun 7: 12627

98. Schmeisser MJ (2015) Translational neurobiology in Shank mutant mice-model systems for neuropsychiatric disorders. Ann Anat 200:115-117

99. Schmeisser MJ, Ey E, Wegener S, Bockmann J, Stempel AV, Kuebler A, Janssen AL, Udvardi PT, Shiban E, Spilker C, Balschun D, Skryabin BV et al (2012) Autistic-like behaviours and hyperactivity in mice lacking ProSAP1/Shank2. Nature 486(7402):256-260

100. Lee Y, Ryu JR, Kang H, Kim Y, Kim S, Zhang Y, Jin C, Cho HM, Kim WK, Sun W, Han K (2017) Characterization of the zincinduced Shank3 interactome of mouse synaptosome. Biochem Biophys Res Commun 494(3-4):581-586

101. Kolevzon A, Angarita B, Bush L, Wang AT, Frank Y, Yang A, Rapaport R, Saland J, Srivastava S, Farrell C, Edelmann LJ, Buxbaum JD (2014) Phelan-McDermid syndrome: a review of the literature and practice parameters for medical assessment and monitoring. J Neurodev Disord 6(1):39

102. Frye RE, Cox D, Slattery J, Tippett M, Kahler S, Granpeesheh D, Damle S, Legido A, Goldenthal MJ (2016) Mitochondrial dysfunction may explain symptom variation in Phelan-McDermid Syndrome. Sci Rep 6:19544

103. Telias M (2019) Molecular mechanisms of synaptic dysregulation in fragile X syndrome and autism spectrum disorders. Front Mol Neurosci 12:51

104. Huber KM, Gallagher SM, Warren ST, Bear MF (2002) Altered synaptic plasticity in a mouse model of fragile $\mathrm{X}$ mental retardation. Proc Natl Acad Sci U S A 99(11):7746-7750

105. Hagerman R, Hoem G, Hagerman P (2010) Fragile X and autism: intertwined at the molecular level leading to targeted treatments. Mol Autism 1(1):12

106. Peprah E (2012) Fragile X syndrome: the FMR1 CGG repeat distribution among world populations. Ann Hum Genet 76(2): 178-191

107. el Bekay R, Romero-Zerbo Y, Decara J, Sanchez-Salido L, Del Arco-Herrera I, Rodriguez-de Fonseca F, de Diego-Otero Y (2007) Enhanced markers of oxidative stress, altered antioxidants and NADPH-oxidase activation in brains from Fragile X mental retardation 1-deficient mice, a pathological model for Fragile $\mathrm{X}$ syndrome. Eur J Neurosci 26(11):3169-3180

108. Kaplan ES, Cao Z, Hulsizer S, Tassone F, Berman RF, Hagerman PJ, Pessah IN (2012) Early mitochondrial abnormalities in hippocampal neurons cultured from Fmr1 pre-mutation mouse model. J Neurochem 123(4):613-621

109. Shen M, Wang F, Li M, Sah N, Stockton ME, Tidei JJ, Gao Y, Korabelnikov T, Kannan S, Vevea JD, Chapman ER, Bhattacharyya A, van Praag H, Zhao X (2019) Reduced mitochondrial fusion and Huntingtin levels contribute to impaired dendritic maturation and behavioral deficits in Fmr1-mutant mice. Nat Neurosci 22(3):386-400

110. Napoli E, Ross-Inta C, Song G, Wong S, Hagerman R, Gane LW, Smilowitz JT, Tassone F, Giulivi C (2016) Premutation in the Fragile X Mental Retardation 1 (FMR1) gene affects maternal 
Zn-milk and perinatal brain bioenergetics and scaffolding. Front Neurosci 10:159

111. Napoli E, Ross-Inta C, Wong S, Omanska-Klusek A, Barrow C, Iwahashi C, Garcia-Arocena D, Sakaguchi D, Berry-Kravis E, Hagerman R, Hagerman PJ, Giulivi C (2011) Altered zinc transport disrupts mitochondrial protein processing/import in fragile $\mathrm{X}$ associated tremor/ataxia syndrome. Hum Mol Genet 20(15): 3079-3092

112. Sellier C, Freyermuth F, Tabet R, Tran T, He F, Ruffenach F, Alunni V, Moine H, Thibault C, Page A, Tassone F, Willemsen R, Disney MD, Hagerman PJ, Todd PK, Charlet-Berguerand N (2013) Sequestration of DROSHA and DGCR8 by expanded CGG RNA repeats alters microRNA processing in fragile Xassociated tremor/ataxia syndrome. Cell Rep 3(3):869-880

113. D'Antoni S, de Bari L, Valenti D, Borro M, Bonaccorso CM, Simmaco M, Vacca RA, Catania MV (2019) Aberrant mitochondrial bioenergetics in the cerebral cortex of the Fmrl knockout mouse model of fragile X syndrome. Biol Chem. https://doi.org/ 10.1515/hsz-2019-0221

114. Griffiths KK, Wang A, Wang L, Tracey M, Kleiner G, Quinzii CM, Sun L, Yang G, Perez-Zoghbi JF, Licznerski P, Yang M, Jonas EA, Levy RJ (2020) Inefficient thermogenic mitochondrial respiration due to futile proton leak in a mouse model of fragile $\mathrm{X}$ syndrome. FASEB J. https://doi.org/10.1096/fj.202000283RR

115. Kuzniewska B, Cysewski D, Wasilewski M, Sakowska P, Milek J, Kulinski TM, Winiarski M, Kozielewicz P, Knapska E, Dadlez M, Chacinska A, Dziembowski A, Dziembowska M (2020) Mitochondrial protein biogenesis in the synapse is supported by local translation. EMBO Rep 21:e48882

116. Weisz ED, Towheed A, Monyak RE, Toth MS, Wallace DC, Jongens TA (2018) Loss of Drosophila FMRP leads to alterations in energy metabolism and mitochondrial function. Hum Mol Genet 27(1):95-106

117. Sullivan KE (2019) Chromosome 22q11.2 deletion syndrome and DiGeorge syndrome. Immunol Rev 287(1):186-201

118. Tastuzawa Y, Sekikawa K, Suda T, Matsumoto H, Otabe H, Nonoyama S, Yoshino A (2015) An interictal schizophrenia-like psychosis in an adult patient with 22q11.2 deletion syndrome. Epilepsy Behav Case Rep 3:36-38

119. Francisco AA, Foxe JJ, Horsthuis DJ, DeMaio D, Molholm S (2020) Assessing auditory processing endophenotypes associated with Schizophrenia in individuals with 22q11.2 deletion syndrome. Transl Psychiatry 10(1):85

120. McDonald-McGinn DM, Sullivan KE, Marino B, Philip N, Swillen A, Vorstman JA, Zackai EH, Emanuel BS, Vermeesch JR, Morrow BE, Scambler PJ, Bassett AS (2015) 22q11.2 deletion syndrome. Nat Rev Disease Primers 1:15071

121. Devaraju P, Zakharenko SS (2017) Mitochondria in complex psychiatric disorders: Lessons from mouse models of 22q11.2 deletion syndrome: Hemizygous deletion of several mitochondrial genes in the 22q11.2 genomic region can lead to symptoms associated with neuropsychiatric disease. Bioessays 39(2):1600177

122. Fernandez A, Meechan DW, Karpinski BA, Paronett EM, Bryan CA, Rutz HL, Radin EA, Lubin N, Bonner ER, Popratiloff A, Rothblat LA, Maynard TM, LaMantia AS (2019) Mitochondrial dysfunction leads to cortical under-connectivity and cognitive impairment. Neuron 102(6):1127-1142 e1123

123. Gokhale A, Hartwig C, Freeman AAH, Bassell JL, Zlatic SA, Sapp Savas C, Vadlamudi T, Abudulai F, Pham TT, Crocker A, Werner E, Wen Z, Repetto GM, Gogos JA, Claypool SM, Forsyth JK, Bearden CE, Glausier J, Lewis DA, Seyfried NT, Kwong JQ, Faundez V (2019) Systems analysis of the 22q11.2 microdeletion syndrome converges on a mitochondrial interactome necessary for synapse function and behavior. J Neurosci 39(18):3561-3581

124. Devaraju P, Yu J, Eddins D, Mellado-Lagarde MM, Earls LR, Westmoreland JJ, Quarato G, Green DR, Zakharenko SS (2017)
Haploinsufficiency of the 22q11.2 microdeletion gene Mrp140 disrupts short-term synaptic plasticity and working memory through dysregulation of mitochondrial calcium. Mol Psychiatry 22(9): 1313-1326

125. Shah RR, Bird AP (2017) MeCP2 mutations: progress towards understanding and treating Rett syndrome. Genome Medicine 9(1): 17

126. Amir RE, Van den Veyver IB, Wan M, Tran CQ, Francke U, Zoghbi HY (1999) Rett syndrome is caused by mutations in Xlinked MECP2, encoding methyl-CpG-binding protein 2. Nat Genet 23(2):185-188

127. Percy AK (2011) Rett syndrome: exploring the autism link. Arch Neurol 68(8):985-989

128. Belichenko PV, Wright EE, Belichenko NP, Masliah E, Li HH, Mobley WC, Francke U (2009) Widespread changes in dendritic and axonal morphology in Mecp2-mutant mouse models of Rett syndrome: evidence for disruption of neuronal networks. J Comp Neurol 514(3):240-258

129. Grosser E, Hirt U, Janc OA, Menzfeld C, Fischer M, Kempkes B, Vogelgesang S, Manzke TU, Opitz L, Salinas-Riester G, Muller M (2012) Oxidative burden and mitochondrial dysfunction in a mouse model of Rett syndrome. Neurobiol Dis 48(1):102-114

130. De Felice C, Della Ragione F, Signorini C, Leoncini S, Pecorelli A, Ciccoli L, Scalabri F, Marracino F, Madonna M, Belmonte G, Ricceri L, De Filippis B, Laviola G, Valacchi G, Durand T, Galano JM, Oger C, Guy A, Bultel-Ponce V, Guy J, Filosa S, Hayek J, D'Esposito M (2014) Oxidative brain damage in Mecp2-mutant murine models of Rett syndrome. Neurobiol Dis 68:66-77

131. Janc OA, Muller M (2014) The free radical scavenger Trolox dampens neuronal hyperexcitability, reinstates synaptic plasticity, and improves hypoxia tolerance in a mouse model of Rett syndrome. Front Cell Neurosci 8:56

132. Bebensee DF, Can K, Muller M (2017) Increased mitochondrial mass and cytosolic redox imbalance in hippocampal astrocytes of a mouse model of rett syndrome: subcellular changes revealed by ratiometric imaging of JC-1 and roGFP1 fluorescence. Oxidative Med Cell Longev 2017:3064016

133. Zuliani I, Urbinati C, Valenti D, Quattrini MC, Medici V, Cosentino L, Pietraforte D, Di Domenico F, Perluigi M, Vacca RA, De Filippis B (2020) The anti-diabetic drug metformin rescues aberrant mitochondrial activity and restrains oxidative stress in a female mouse model of Rett syndrome. J Clin Med 9(6):1669

134. Dave A, Shukla F, Wala H, Pillai P (2019) Mitochondrial electron transport chain complex dysfunction in MeCP2 knock-down astrocytes: protective effects of quercetin hydrate. J Mol Neurosci 67(1):16-27

135. Jin LW, Horiuchi M, Wulff H, Liu XB, Cortopassi GA, Erickson JD, Maezawa I (2015) Dysregulation of glutamine transporter SNAT1 in Rett syndrome microglia: a mechanism for mitochondrial dysfunction and neurotoxicity. J Neurosci 35(6):2516-2529

136. Forlani G, Giarda E, Ala U, Di Cunto F, Salani M, Tupler R, Kilstrup-Nielsen C, Landsberger N (2010) The MeCP2/YY1 interaction regulates ANT1 expression at 4q35: novel hints for Rett syndrome pathogenesis. Hum Mol Genet 19(16):3114-3123

137. Sharer JD (2005) The adenine nucleotide translocase type 1 (ANT1): a new factor in mitochondrial disease. IUBMB Life 57(9):607-614

138. Jordens EZ, Palmieri L, Huizing M, van den Heuvel LP, Sengers RC, Dorner A, Ruitenbeek W, Trijbels FJ, Valsson J, Sigfusson G, Palmieri F, Smeitink JA (2002) Adenine nucleotide translocator 1 deficiency associated with Sengers syndrome. Ann Neurol 52(1): 95-99

139. Urdinguio RG, Lopez-Serra L, Lopez-Nieva P, Alaminos M, Diaz-Uriarte R, Fernandez AF, Esteller M (2008) Mecp2-null 
mice provide new neuronal targets for Rett syndrome. PLoS One 3(11):e3669

140. Di Rosa G, Pustorino G, Spano M, Campion D, Calabro M, Aguennouz M, Caccamo D, Legallic S, Sgro DL, Bonsignore M, Tortorella G (2008) Type I hyperprolinemia and proline dehydrogenase (PRODH) mutations in four Italian children with epilepsy and mental retardation. Psychiatr Genet 18(1):40-42

141. De Filippis B, Valenti D, de Bari L, De Rasmo D, Musto M, Fabbri A, Ricceri L, Fiorentini C, Laviola G, Vacca RA (2015) Mitochondrial free radical overproduction due to respiratory chain impairment in the brain of a mouse model of Rett syndrome: protective effect of CNF1. Free Radic Biol Med 83:167-177

142. De Filippis B, Valenti D, Chiodi V, Ferrante A, de Bari L, Fiorentini C, Domenici MR, Ricceri L, Vacca RA, Fabbri A, Laviola G (2015) Modulation of Rho GTPases rescues brain mitochondrial dysfunction, cognitive deficits and aberrant synaptic plasticity in female mice modeling Rett syndrome. Eur Neuropsychopharmacol 25(6):889-901

143. Valenti D, de Bari L, Vigli D, Lacivita E, Leopoldo M, Laviola G, Vacca RA, De Filippis B (2017) Stimulation of the brain serotonin receptor 7 rescues mitochondrial dysfunction in female mice from two models of Rett syndrome. Neuropharmacology 121:79-88

144. Can K, Menzfeld C, Rinne L, Rehling P, Kugler S, Golubiani G, Dudek J, Muller M (2019) Neuronal redox-imbalance in Rett Syndrome affects mitochondria as well as cytosol, and is accompanied by intensified mitochondrial O 2 consumption and ROS release. Front Physiol 10:479

145. Kriaucionis S, Paterson A, Curtis J, Guy J, Macleod N, Bird A (2006) Gene expression analysis exposes mitochondrial abnormalities in a mouse model of Rett syndrome. Mol Cell Biol 26(13):5033-5042

146. Shulyakova N, Andreazza AC, Mills LR, Eubanks JH (2017) Mitochondrial dysfunction in the pathogenesis of Rett syndrome: implications for mitochondria-targeted therapies. Front Cell Neurosci 11:58

147. Vignoli A, La Briola F, Peron A, Turner K, Vannicola C, Saccani M, Magnaghi E, Scornavacca GF, Canevini MP (2015) Autism spectrum disorder in tuberous sclerosis complex: searching for risk markers. Orphanet J Rare Diseases 10:154

148. Huang J, Manning BD (2008) The TSC1-TSC2 complex: a molecular switchboard controlling cell growth. Biochem J 412(2): 179-190

149. Ebrahimi-Fakhari D, Saffari A, Wahlster L, Di Nardo A, Turner D, Lewis TL Jr, Conrad C, Rothberg JM, Lipton JO, Kolker S, Hoffmann GF, Han MJ, Polleux F, Sahin M (2016) Impaired mitochondrial dynamics and mitophagy in neuronal models of tuberous sclerosis complex. Cell Rep 17(4):1053-1070

150. Meikle L, Talos DM, Onda H, Pollizzi K, Rotenberg A, Sahin M, Jensen FE, Kwiatkowski DJ (2007) A mouse model of tuberous sclerosis: neuronal loss of Tsc1 causes dysplastic and ectopic neurons, reduced myelination, seizure activity, and limited survival. J Neurosci 27(21):5546-5558

151. Ebrahimi-Fakhari D, Saffari A, Wahlster L, Sahin M (2017) Using tuberous sclerosis complex to understand the impact of MTORC1 signaling on mitochondrial dynamics and mitophagy in neurons. Autophagy 13(4):754-756

152. Vatsa N, Jana NR (2018) UBE3A and its link with autism. Front Mol Neurosci 11:448

153. Smith SE, Zhou YD, Zhang G, Jin Z, Stoppel DC, Anderson MP (2011) Increased gene dosage of Ube3a results in autism traits and decreased glutamate synaptic transmission in mice. Sci Transl Med 3(103): 103ra197

154. Frye RE (2009) 15q11.2-13 duplication, mitochondrial dysfunction, and developmental disorders. J Child Neurol 24(10):13161320
155. Jiang YH, Armstrong D, Albrecht U, Atkins CM, Noebels JL, Eichele G, Sweatt JD, Beaudet AL (1998) Mutation of the Angelman ubiquitin ligase in mice causes increased cytoplasmic p53 and deficits of contextual learning and long-term potentiation. Neuron 21(4):799-811

156. Burette AC, Judson MC, Burette S, Phend KD, Philpot BD, Weinberg RJ (2017) Subcellular organization of UBE3A in neurons. J Comp Neurol 525(2):233-251

157. Su H, Fan W, Coskun PE, Vesa J, Gold JA, Jiang YH, Potluri P, Procaccio V, Acab A, Weiss JH, Wallace DC, Kimonis VE (2011) Mitochondrial dysfunction in CA1 hippocampal neurons of the UBE3A deficient mouse model for Angelman syndrome. Neurosci Lett 487(2):129-133

158. Llewellyn KJ, Nalbandian A, Gomez A, Wei D, Walker N, Kimonis VE (2015) Administration of CoQ10 analogue ameliorates dysfunction of the mitochondrial respiratory chain in a mouse model of Angelman syndrome. Neurobiol Dis 76:77-86

159. McManus MJ, Murphy MP, Franklin JL (2011) The mitochondria-targeted antioxidant MitoQ prevents loss of spatial memory retention and early neuropathology in a transgenic mouse model of Alzheimer's disease. J Neurosci 31(44): $15703-15715$

160. Santini E, Turner KL, Ramaraj AB, Murphy MP, Klann E, Kaphzan H (2015) Mitochondrial superoxide contributes to hippocampal synaptic dysfunction and memory deficits in Angelman Syndrome model mice. J Neurosci 35(49):16213-16220

161. Dykens EM, Lee E, Roof E (2011) Prader-Willi syndrome and autism spectrum disorders: an evolving story. J Neurodev Disord 3(3):225-237

162. Yazdi PG, Su H, Ghimbovschi S, Fan W, Coskun PE, Nalbandian A, Knoblach S, Resnick JL, Hoffman E, Wallace DC, Kimonis VE (2013) Differential gene expression reveals mitochondrial dysfunction in an imprinting center deletion mouse model of PraderWilli syndrome. Clin Transl Sci 6(5):347-355

163. Head E, Powell D, Gold BT, Schmitt FA (2012) Alzheimer's disease in Down syndrome. Eur J Neurodegener Dis 1(3):353364

164. DiGuiseppi C, Hepburn S, Davis JM, Fidler DJ, Hartway S, Lee NR, Miller L, Ruttenber M, Robinson C (2010) Screening for autism spectrum disorders in children with Down syndrome: population prevalence and screening test characteristics. J Dev Behav Pediatr 31(3):181-191

165. Oxelgren UW, Myrelid A, Anneren G, Ekstam B, Goransson C, Holmbom A, Isaksson A, Aberg M, Gustafsson J, Fernell E (2017) Prevalence of autism and attention-deficit-hyperactivity disorder in Down syndrome: a population-based study. Dev Med Child Neurol 59(3):276-283

166. Channell MM, Hahn LJ, Rosser TC, Hamilton D, Frank-Crawford MA, Capone GT, Sherman SL, Down Syndrome Cognition P (2019) Characteristics associated with autism spectrum disorder risk in individuals with Down syndrome. J Autism Dev Disord 49(9):3543-3556

167. Geier DA, Kern JK, Geier MR (2019) Down syndrome as a genetic model to evaluate the role of oxidative stress and transsulfuration abnormalities in autism spectrum disorder: a 10year longitudinal cohort study. Dev Neurobiol 79(9-10):857-867

168. Moss J, Richards C, Nelson L, Oliver C (2013) Prevalence of autism spectrum disorder symptomatology and related behavioural characteristics in individuals with Down syndrome. Autism 17(4):390-404

169. Rachubinski AL, Hepburn S, Elias ER, Gardiner K, Shaikh TH (2017) The co-occurrence of Down syndrome and autism spectrum disorder: is it because of additional genetic variations? Prenat Diagn 37(1):31-36

170. Channell MM, Phillips BA, Loveall SJ, Conners FA, Bussanich PM, Klinger LG (2015) Patterns of autism spectrum 
symptomatology in individuals with Down syndrome without comorbid autism spectrum disorder. J Neurodev Disord 7(1):5

171. Izzo A, Mollo N, Nitti M, Paladino S, Cali G, Genesio R, Bonfiglio F, Cicatiello R, Barbato M, Sarnataro V, Conti A, Nitsch L (2018) Mitochondrial dysfunction in down syndrome: molecular mechanisms and therapeutic targets. Mol Med 24(1):2

172. Zamponi E, Helguera PR (2019) The shape of mitochondrial dysfunction in Down syndrome. Dev Neurobiol 79(7):613-621

173. Valenti D, Rossi L, Marzulli D, Bellomo F, De Rasmo D, Signorile A, Vacca RA (2017) Inhibition of Drp1-mediated mitochondrial fission improves mitochondrial dynamics and bioenergetics stimulating neurogenesis in hippocampal progenitor cells from a Down syndrome mouse model. Biochim Biophys Acta Mol basis Dis 1863(12):3117-3127

174. Shukkur EA, Shimohata A, Akagi T, Yu W, Yamaguchi M, Murayama M, Chui D, Takeuchi T, Amano K, Subramhanya KH, Hashikawa T, Sago H, Epstein CJ, Takashima A, Yamakawa K (2006) Mitochondrial dysfunction and tau hyperphosphorylation in Ts1Cje, a mouse model for Down syndrome. Hum Mol Genet 15(18):2752-2762

175. Gardiner KJ (2015) Pharmacological approaches to improving cognitive function in Down syndrome: current status and considerations. Drug Design Dev Ther 9:103-125

176. De la Torre R, De Sola S, Pons M, Duchon A, de Lagran MM, Farre M, Fito M, Benejam B, Langohr K, Rodriguez J, Pujadas M, Bizot JC, Cuenca A, Janel N, Catuara S, Covas MI, Blehaut H, Herault Y, Delabar JM, Dierssen M (2014) Epigallocatechin-3gallate, a DYRK1A inhibitor, rescues cognitive deficits in Down syndrome mouse models and in humans. Mol Nutr Food Res 58(2):278-288

177. Shichiri M, Yoshida Y, Ishida N, Hagihara Y, Iwahashi H, Tamai H, Niki E (2011) alpha-Tocopherol suppresses lipid peroxidation and behavioral and cognitive impairments in the Ts65Dn mouse model of Down syndrome. Free Radic Biol Med 50(12):18011811

178. Le Duc D, Giulivi C, Hiatt SM, Napoli E, Panoutsopoulos A, Harlan De Crescenzo A, Kotzaeridou U, Syrbe S, Anagnostou E, Azage M, Bend R et al (2019) Pathogenic WDFY3 variants cause neurodevelopmental disorders and opposing effects on brain size. Brain 142(9):2617-2630

179. Napoli E, Song G, Panoutsopoulos A, Riyadh MA, Kaushik G, Halmai J, Levenson R, Zarbalis KS, Giulivi C (2018) Beyond autophagy: a novel role for autism-linked Wdfy3 in brain mitophagy. Sci Rep 8(1):11348

180. Xie Z, Jones A, Deeney JT, Hur SK, Bankaitis VA (2016) Inborn errors of long-chain fatty acid beta-oxidation link neural stem cell self-renewal to autism. Cell Rep 14(5):991-999

181. Ahn Y, Sabouny R, Villa BR, Yee NC, Mychasiuk R, Uddin GM, Rho JM, Shutt TE (2020) Aberrant mitochondrial morphology and function in the BTBR mouse model of autism is improved by two weeks of ketogenic diet. Int J Mol Sci 21(9):3266

182. Mychasiuk R, Rho JM (2017) Genetic modifications associated with ketogenic diet treatment in the BTBR $(\mathrm{T}+\mathrm{Tf} / \mathrm{J})$ mouse model of autism spectrum disorder. Autism Res 10(3):456-471

183. Newell C, Shutt TE, Ahn Y, Hittel DS, Khan A, Rho JM, Shearer J (2016) Tissue specific impacts of a ketogenic diet on mitochondrial dynamics in the BTBR(T+tf/j) mouse. Front Physiol 7:654

184. Cristiano C, Pirozzi C, Coretti L, Cavaliere G, Lama A, Russo R, Lembo F, Mollica MP, Meli R, Calignano A, Mattace Raso G (2018) Palmitoylethanolamide counteracts autistic-like behaviours in BTBR T+tf/J mice: contribution of central and peripheral mechanisms. Brain Behav Immun 74:166-175

185. Schwede M, Nagpal S, Gandal MJ, Parikshak NN, Mirnics K, Geschwind DH, Morrow EM (2018) Strong correlation of downregulated genes related to synaptic transmission and mitochondria in post-mortem autism cerebral cortex. J Neurodev Disord 10(1): 18

186. Napolioni V, Persico AM, Porcelli V, Palmieri L (2011) The mitochondrial aspartate/glutamate carrier AGC1 and calcium homeostasis: physiological links and abnormalities in autism. Mol Neurobiol 44(1):83-92

187. Egawa J, Watanabe Y, Wang C, Inoue E, Sugimoto A, Sugiyama T, Igeta H, Nunokawa A, Shibuya M, Kushima I, Orime N, Hayashi T, Okada T, Uno Y, Ozaki N, Someya T (2015) Novel rare missense variations and risk of autism spectrum disorder: whole-exome sequencing in two families with affected siblings and a two-stage follow-up study in a Japanese population. PLoS One 10(3): e0119413

188. Lewerenz J, Hewett SJ, Huang Y, Lambros M, Gout PW, Kalivas PW, Massie A, Smolders I, Methner A, Pergande M, Smith SB, Ganapathy V, Maher P (2013) The cystine/glutamate antiporter system $\mathrm{x}(\mathrm{c})(-)$ in health and disease: from molecular mechanisms to novel therapeutic opportunities. Antioxid Redox Signal 18(5): 522-555

189. Lewerenz J, Klein M, Methner A (2006) Cooperative action of glutamate transporters and cystine/glutamate antiporter system Xc- protects from oxidative glutamate toxicity. J Neurochem 98(3):916-925

190. Bentea E, Villers A, Moore C, Funk AJ, O’Donovan SM, Verbruggen L, Lara O, Janssen P, De Pauw L, Declerck NB, DePasquale EAK, Churchill MJ, Sato H, Hermans E, Arckens L, Meshul CK, Ris L, McCullumsmith RE, Massie A (2020) Corticostriatal dysfunction and social interaction deficits in mice lacking the cystine/glutamate antiporter. Mol Psychiatry. https:// doi.org/10.1038/s41380-020-0751-3

191. Fecher C, Trovo L, Muller SA, Snaidero N, Wettmarshausen J, Heink S, Ortiz O, Wagner I, Kuhn R, Hartmann J, Karl RM, Konnerth A, Korn T, Wurst W, Merkler D, Lichtenthaler SF, Perocchi F, Misgeld T (2019) Cell-type-specific profiling of brain mitochondria reveals functional and molecular diversity. Nat Neurosci 22(10):1731-1742

192. Filice F, Schwaller B (2017) Parvalbumin and autism: different causes, same effect? Oncotarget 8(5):7222-7223

193. Lauber E, Filice F, Schwaller B (2018) Parvalbumin neurons as a hub in autism spectrum disorders. J Neurosci Res 96(3):360-361

194. Caillard O, Moreno H, Schwaller B, Llano I, Celio MR, Marty A (2000) Role of the calcium-binding protein parvalbumin in shortterm synaptic plasticity. Proc Natl Acad Sci U S A 97(24):1337213377

195. Mauceri D, Hagenston AM, Schramm K, Weiss U, Bading H (2015) Nuclear calcium buffering capacity shapes neuronal architecture. J Biol Chem 290(38):23039-23049

196. Chard PS, Bleakman D, Christakos S, Fullmer CS, Miller RJ (1993) Calcium buffering properties of calbindin D28k and parvalbumin in rat sensory neurones. J Physiol 472:341-357

197. Janickova L, Rechberger KF, Wey L, Schwaller B (2020) Absence of parvalbumin increases mitochondria volume and branching of dendrites in inhibitory Pvalb neurons in vivo: a point of convergence of autism spectrum disorder (ASD) risk gene phenotypes. Mol Autism 11(1):47

198. Legido A, Jethva R, Goldenthal MJ (2013) Mitochondrial dysfunction in autism. Semin Pediatr Neurol 20(3):163-175

199. Rossignol DA, Frye RE (2012) Mitochondrial dysfunction in autism spectrum disorders: a systematic review and meta-analysis. Mol Psychiatry 17(3):290-314

200. Griffiths KK, Levy RJ (2017) Evidence of mitochondrial dysfunction in autism: biochemical links, genetic-based associations, and non-energy-related mechanisms. Oxidative Med Cell Longev 2017:4314025

201. Rose S, Niyazov DM, Rossignol DA, Goldenthal M, Kahler SG, Frye RE (2018) Clinical and molecular characteristics of 
mitochondrial dysfunction in autism spectrum disorder. Mol Diagn Ther 22(5):571-593

202. Siddiqui MF, Elwell C, Johnson MH (2016) Mitochondrial dysfunction in autism spectrum disorders. Autism Open Access 6(5): 1000190

203. Weissman JR, Kelley RI, Bauman ML, Cohen BH, Murray KF, Mitchell RL, Kern RL, Natowicz MR (2008) Mitochondrial disease in autism spectrum disorder patients: a cohort analysis. PLoS One 3(11):e3815

204. Tang G, Gutierrez Rios P, Kuo SH, Akman HO, Rosoklija G, Tanji K, Dwork A, Schon EA, Dimauro S, Goldman J, Sulzer D (2013) Mitochondrial abnormalities in temporal lobe of autistic brain. Neurobiol Dis 54:349-361

205. Petersen MH, Willert CW, Andersen JV, Waagepetersen HS, Skotte NH, Norremolle A (2019) Functional differences between synaptic mitochondria from the striatum and the cerebral cortex. Neuroscience 406:432-443

206. Burtscher J, Zangrandi L, Schwarzer C, Gnaiger E (2015) Differences in mitochondrial function in homogenated samples from healthy and epileptic specific brain tissues revealed by high-resolution respirometry. Mitochondrion 25:104-112

207. Lee A, Hirabayashi Y, Kwon SK, Lewis TL Jr, Polleux F (2018) Emerging roles of mitochondria in synaptic transmission and neurodegeneration. Curr Opin Physiol 3:82-93

208. Graybiel AM, Grafton ST (2015) The striatum: where skills and habits meet. Cold Spring Harb Perspect Biol 7(8):a021691

209. Rasia-Filho AA, Londero RG, Achaval M (2000) Functional activities of the amygdala: an overview. J Psychiatry Neurosci 25(1): 14-23

210. Pickrell AM, Fukui H, Wang X, Pinto M, Moraes CT (2011) The striatum is highly susceptible to mitochondrial oxidative phosphorylation dysfunctions. J Neurosci 31(27):9895-9904

211. Mirandola SR, Melo DR, Saito A, Castilho RF (2010) 3nitropropionic acid-induced mitochondrial permeability transition: comparative study of mitochondria from different tissues and brain regions. J Neurosci Res 88(3):630-639

Publisher's note Springer Nature remains neutral with regard to jurisdictional claims in published maps and institutional affiliations. 